\title{
Review of the Neotropical Charipinae (Hymenoptera, Cynipoidea, Figitidae)
}

\author{
Mar Ferrer-Suay ${ }^{1,3}$, Jesús Selfa² \& Juli Pujade-Villar ${ }^{1}$
}

\begin{abstract}
'Departamento de Biologia Animal, Facultat de Biologia, Universitat de Barcelona, Avda. Diagonal 645, 08028-Barcelona, Spain. jpujade@ub.edu ${ }^{2}$ Departamento de Zoologia, Facultat de Ciències Biològiques, Universitat de València, Campus de Burjassot-Paterna, Dr. Moliner 50, E-46100 Burjassot (València), Spain. jesus.selfa@uv.es

${ }^{3}$ Corresponding author. mar.ferrer.suay@gmail.com
\end{abstract}

\begin{abstract}
Review of the Neotropical Charipinae (Hymenoptera, Cynipoidea, Figitidae). A review of the Neotropical Charipinae is given, with 35 species from four genera: Alloxysta, Apocharips, Dilyta and Phaenoglyphis. One new species, Alloxysta centroamericana Ferrer-Suay \& Pujade-Villar sp. nov. is described; six Alloxysta species, Alloxysta citripes (Thomson, 1862), Alloxysta fracticornis (Thomson, 1862), Alloxysta melanogaster (Hartig, 1841), Alloxysta piceomaculata (Cameron, 1886), Alloxysta postica (Hartig, 1841) and Alloxysta pusilla (Kieffer, 1902), are recorded for the first time from the Neotropical region; 10 new records for earlier known species are also given. Diagnoses and a key to all species are also provided.
\end{abstract}

KEYWORDS. Charipinae; Insecta; Neotropical region.

Members of the subfamily Charipinae (Hymenoptera, Cynipoidea, Figitidae) are morphologically characterized as very small wasps $(0.8-2.0 \mathrm{~mm})$ with shiny and smooth bodies and few diagnostic features. This has led to a chaotic and diverse subfamily. The taxonomic chaos of the subfamily Charipinae is an obstacle to species identification. The limits between species are not always clear, mainly because authors gave special attention to size and coloration of specimens, neglecting useful structural differences. For these reasons, many taxonomic inconsistences and numerous synonymies need to be tackled (Ferrer-Suay et al. 2012a).

Charipinae are secondary parasitoids of aphids via Aphidiinae (Hymenoptera, Braconidae) and Aphelininae (Hymenoptera, Aphelinidae) and secondary parasitoids of psyllids via Encyrtidae (Hymenoptera, Chalcidoidea) (Menke \& Evenhuis 1991). It is important to note that as hyperparasitoids the Charipinae could interfere with biological control using the primary parasitoids of aphids.

The Charipinae are widely distributed, being cited in all biogeographical regions. The first species described in this subfamily was Alloxysta victrix by Westwood (1833). Since then, the number of species of Charipinae has increased to a total of 281 species described, of which 168 are currently considered valid (Ferrer-Suay et al. 2012a). Neotropical Charipinae have been studied in many previous works. Andrews (1976) described a new species of Alloxysta from Argentina and Chile. Pujade-Villar et al. (2002) revised the Charipinae from South America and described two new species. Paretas-Martínez \& Pujade-Villar (2007) also revised the Charipinae of the Neotropical region. The Charipinae from Costa Rica, Colombia and Mexico have been studied by Ferrer-Suay et al. (2011), Ferrer-Suay et al. (2012b), Ferrer-Suay et al. (2013a). Recently, the genus Dilyta was recorded for the first time from the Neotropics (Mexico) in Ferrer-Suay et al. (2012d).
With these previous studies, the Neotropical Charipinae fauna now includes 35 species: Alloxysta andrewsi, Al. arcuata, Al. brevis, Al. castanea, Al. citripes, Al. costaricensis, Al. desantisi, Al. evenhuisi, Al. fracticornis, Al. fuscicornis, Al. hansoni, Al. luismii, Al. medinae, Al. melanogaster, Al. centroamericana, Al. mexicana, Al. mullensis, Al. nothofagi, Al. obscurata, Al. piceomaculata, Al. pilipennis, Al. postica, Al. pusilla, Al. sarae, Al. torresii, Al. victrix, Apocharips angelicae, Ap. hansoni, Dilyta paretasmartinezi, Phaenoglyphis americana, $P$. calverti, $P$. falcata, . stenos, $P$. stricta and $P$. villosa. One new species is here described: Alloxysta centroamericana. Six species are here cited for the first time from the Neotropical region: Al. citripes, Al. fracticornis, Al. melanogaster, Al. piceomaculata, Al. postica and Al. pusilla. Ten new country records are established.

\section{MATERIAL AND METHODS}

Specimens were studied using a stereo microscope (NIKON SMZ-1) and environmental scanning electron microscope (FEI Quanta 200 ESEM). The field-emission gun environmental scanning electron microscope was used for high-resolution imaging without gold-coating of the specimens.

Material studied is deposited in the following institutions: BMNH: Natural History Museum (London, United Kingdom); CNCI: Canadian National Collection of Insects (Ottawa, Canada); IAvH: Instituto Alexander von Humboldt (Villa de Leiva, Colombia); MZLU: Lund Museum of Zoology (Lund, Sweden); NHMA: Natural History Museum (Amiens, France); NMW: Naturhistorische Museum Wien (Vienna, Austria); OUMNH: Hope Department of Entomology (Oxford, England); UAEM: Universidad Autónoma del Estado de México; UAEM Morelos: Universidad Autónoma del Estado de Morelos (México); UB: Universitat de 
Barcelona (col. JP-V, Spain); UCR: Universidad de Costa Rica (San Pedro, Costa Rica); USNM: United States National Museum of Natural History (Smithsonian Institution) (Washington, United States); ZSM: Zoologische Staatssammlung Museum (München, Germany).

Morphological terms used are taken from Paretas-Martínez et al. (2007). Measurements and abbreviations include F1-F12, first and subsequent flagellomeres. The width of the forewing radial cell is measured from the margin of the wing to the beginning Rs vein. The transfacial line is measured as the distance between the inner margins of compound eyes, measured across the face through the antennal sockets divided by the height of the eye. The malar space is measured by the distance from the lower part of the gena from the mouthparts to the ventral margin of the compound eye, divided by the height of the eye. Females and males of the species shortly described have the same characters except where indicated.

Figure 1 shows the types of mesopleuron and metasoma present in the Charipinae from the Neotropical region. For better comparisson antennae of Alloxysta species are grouped in Figure 2 and 3, antennae from Apocharips, Dilyta and Phaenoglyphis are grouped in Figure 4, radial cell of Alloxysta species in Figure 5, radial cell of Apocharips and Phaenoglyphis in Figure 6, different types of propodeum in Figure 7 and different types of pronotum in Figure 8. The figure 9 shows the features of Alloxysta centroamericana Ferrer-Suay \& PujadeVillar sp. nov.

\section{TAXONOMY}

\section{Alloxysta Förster, 1869 Alloxysta andrewsi Ferrer-Suay \& Pujade-Villar, 2011}

Diagnosis. Alloxysta andrewsi is mainly characterized having partially open radial cell, pronotal and propodeal carinae present and rhinaria and club shaped begin in F3. It is similar to A. longipennis (Hartig, 1841) but differs in the presence/absence of carinae at the apex of scutellum: present in $A$. andrewsi while absent in A. longipennis; and shape of propodeal carinae: plate with curved sides in $A$. andrews $i$ but with straight sides in A. longipennis.

Short description. Head yellowish brown, mesosoma and metasoma dark brown; scape, pedicel, F1 and F2 yellowish brown, F5-F11 brown; legs dark yellow and veins brown. Female antennae 13-segmented; F1-F2 smooth, thinner than remaining ones; F3-F11 with rhinaria and club shaped; F1 longer than pedicel and F2, F2 subequal to F3, F3 shorter than F4 (Fig. 2a). Pronotum densely covered with long setae at proximal, center and lower corners; distolateral corners and middle of pronotal plate almost bare, pronotal carinae clearly distinguishable. Carinae present in the apex of scutellum. Propodeum with carinae defined in the anterior $2 / 3$ separated by a space densely pubescent, forming a plate on the lower $1 / 3$, strongly curved side, with several carinae at the base of the plate. Forewing longer than body; radial cell partially open, 2.4 times as long as wide (Fig. 5a).
Male unknown.

Distribution. Costa Rica (Ferrer-Suay et al. 2011).

Type material. Deposited in UCR, examined in Ferrer-Suay et al. (2011).

\section{Alloxysta arcuata (Kieffer, 1902)}

Diagnosis. Alloxysta arcuata is mainly characterized having a small closed radial cell, pronotal and propodeal carinae present and rhinaria and club shaped begin in F3. It is similar to A. mullensis but they can be easily differentiated by the presence/absence of pronotal carinae: present in $A$. arcuata (Fig. 8a) but absent in A. mullensis.

Short description. Head yellowish brown in female (more yellowish in male); mesosoma and metasoma dark brown; scape, pedicel, F1 and F2 dark yellow, F3-F12 brown; legs yellow and veins yellowish brown. Female antennae 13-segmented; F1-F2 smooth, thinner than remaining ones; club begins in F3 but it is more evident from F4, F4-F11 with rhinaria; F1 subequal to pedicel, F1 longer than F2, F2-F4 subequal (Fig. 2b). Male antennae 14-segmented; F1 smooth, thinner than remaining flagellomeres, F2-F12 with rhinaria and club shaped; F2 sometimes slightly curved, F1 longer than pedicel, F1 subequal to F2, F2 shorter than F3 and F3 shorter than F4. Pronotum densely pubescent with two carinae clearly visible under the pubescence. Propodeum covered by many setae, with a central plate formed by two carinae with several setae on anterior half; plate margins slightly curved outward. Forewing longer than body; radial cell closed, 2.3 times as long as wide in both sexes (Fig. 5b).

Distribution. Mexico (Ferrer-Suay et al. 2013a) and Colombia (Ferrer-Suay et al. 2012b). New record from Bolivia, Chile, Costa Rica, Dominican Republic, Ecuador, Guatemala, Venezuela and Panamá.

Type material. Deposited in BMNH, examined in Ferrer-Suay et al. (2012c).

Additional examined material $(28 \mathrm{M} \& 65 \mathrm{~F})$. CNCI $(10 \mathrm{M} \& 10 \mathrm{~F}$ deposited in UB): "C63- Bolivia: La Paz, Sorata environs, 3100m, 20.iv.1997, L. Masner, open shrub,sweep": 1M \& 3F; "C-471, Chile: Chiloe T. 100m, Rio Puntra \& Ruta, 24.IV.1988": 2M \& 1F; "Chile: Malleco, Parque Nacional, Tolhuaca 900m, 2.III.78, T. Cekalovic": 1F; "C-38, Chile: Osorno-Puyehue Nat. Park, 12-13-II.1988, Masner PT, Notophagus For.": 1M; “C98- Chile: Región IX, Nahuelbuta Nat. Park, $37.809^{\circ} \mathrm{S} 73.016^{\circ} \mathrm{W}, 3680$ ', 9-12.i.2000, D.W. Webb, D.K. Yates, MT”: 2F; "C90- Chile: Quillota, Campanas Nat. Park, $32.932^{\circ} \mathrm{S} 71.078^{\circ} \mathrm{W}$, 29.xi.1999-13.i.2000, M. Irwin, 250m, MT": 1M; “C101- Chile: Chiloé I., Ahoni Alto, 3-15.ii.1995, A. Ugarte, YPT”: 1F; "C89- Chile: Cautin, 1150 m, Conguillio Nat. Park, 5.ii.1988, L. Masner, Nothofagus/Araucaria forest, sweep": 1M; “C81- Colombia: Valle, above Saladido, 6500', 8.iv.1971, Eberhard \& Garcia": 4M \& 16F; "C78-Colombia: Valle, above Saladito, 6500', roadside low 2nd growth forest, 8.iv.1971, W. Eberhard, L. Garcia": 2M \& 4F; "C80- Colombia: E of Calarcá, Quindio, 700010000', 6-7.iii.1974, J. Peck”: 1F; “C120- Costa Rica: San José, San Gerardo de Bota, Rio Savegre, 18-19.iii.96, 2200m, L. Masner, YPT in riverbed": 1F; "C83- Costa Rica: Cerro de la Muerte, Arroyo Muerte, 3200m, 31.iii.85, L. Masner, sweeping": 3F; "C82- Costa Rica: Hwy \#2, km 95, 8344'W 9³6’N, 3-13.iv.85, 3200m, H. Goulet, L. Masner”: 3F; “C85- Costa Rica, Hwy \#2, km 95, 834' 'W 9³6'N, 1.iv.85, 3200m, H. Goulet, L. Masner”: 1F; “C87- Costa Rica: Hwy \# 2, km 93, 8345’W 


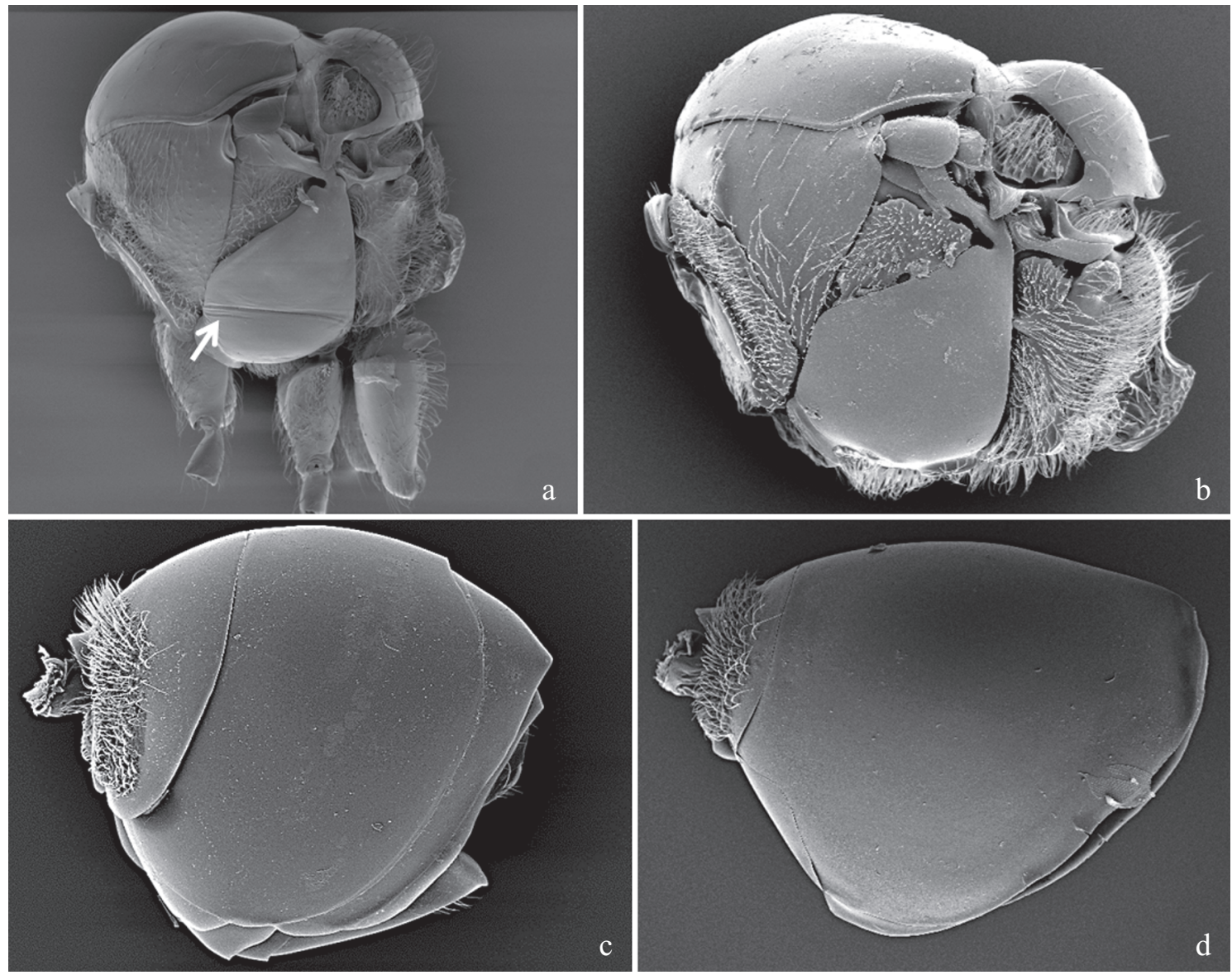

Fig. 1. Types of mesosoma and metasoma of the Charipinae: a) Mesosoma of Phaenoglyphis sp.; b) Mesosoma of Alloxysta sp.; c) Metasoma of Alloxysta sp.; d) Metasoma of Apocharips sp.

9³6’N, iv.85, 3200m, H. Goulet, L. Masner”: $1 \mathrm{M} \& 1 \mathrm{~F}$; “C84- Costa Rica: Hwy \#2, km 95, 8344’W 9³6’N, iv.85, 3200m, H. Goulet, L. Masner": $1 \mathrm{M}$ \& 1F; "Dominican Republic: La Vega, Parque Nac. Armando Bermudez, nr. La Ciénaga, 1000m, FIT, 12-22.I.1989, L. Masner": 1M \& 4F; "C119- Ecuador: Napo, Papallacta, ii.1983, M. Sharkey": 1F; "C107- Guatemala: Zacapa, San Lorenzo, xi.1986, M. Sharkey": 6M \& 4F; "C114- Ecuador: Napo Sierra Azul, 2300m, 2122.iv.1996, P. Hibbs, YPT (18)": 2F; “C-126, Guatemala: Zacapa, San Lorenzo, 7.VIII.1986, L. La Sage sweepers, Mainty Oak.": 2F; "C108Guatemala: Zacapa, above San Lorenzo, xi.1986, 2300m, M. Sharkey": 2F; "C70- Guatemala: Zacapa, San Lorenzo, 1800m, 14-17.vii.1986, attracted with eugenol in abandoned field, L. LeSage": 1F; "C105- Guatemala: Zacapa, San Lorenzo, 7-17.vii.1986, L. LeSage, PT at pine forest edge + field": 1F; "C106- Guatemala: Sacatepequez, above Antigua Guatemala, Volcán Agua, 1700m, 23.xi.1986, M. Sharkey, sweep": 5M \& 2F; "C104- Guatemala: Zacapa, 5 mi. N. San Lorenzo, 24.vi18.viii.1986, J.M. Campbell, FIT": 1M \& 1F; "C68- Guatemala: Chimaltenango, 5 mi S. Acatenango, 2400m, 2.viii.1972, J. Helava": 1M; "C128- Mexico: Chiapas, 3 mi NE San Cristobal de las Casas, 24.v.1969, B.V. Peterson": 1F; "Panamá, Chiriqui Prov, 2Km. W. Cerro Punta, 1700m, 19.V.-8.VI.1977, Peck \& Howden": 1F; “C125- Venezuela: Merida, Merida, Station Roca, 2000m, pan-trap, 15.v-15.vii.1981, Briceño \& Suarez": 1F; Venezuela, Tach. 55Km. N.E. Sn. Cristobal 10,000', 17-18.V.1974, J. Peck": 1F. USNM: "Colombia, Boyacá, SFF Iguaque, Cabaña Chaina, $5^{\circ} 42^{\prime} \mathrm{N} 73^{\circ} 27^{\prime} \mathrm{W}, 2600 \mathrm{~m}$, Malaise, 16.xi1.xii.2001, P. Reina leg. M2583": 1F; "Colombia: Santander, PNN Tamá, Mun. Toledo, Vda. La Camacha, Pozo Negro”, “7² $21^{\prime} \mathrm{N} 72^{\circ} 28^{\prime} \mathrm{W}$, 2213m, Malaise 23.x-2.xi.2003, C. Leal leg. M4029": 1F.

\section{Alloxysta brevis (Thomson, 1862)}

Diagnosis. Alloxysta brevis is mainly characterized having a small closed radial cell, pronotal carinae absent, propodeal carinae present and rhinaria and club shaped begin in F4. It is similar to A. mullensis but they can be differentiated by the antennae length: shorter than body length in A. brevis but longer in A. mullensis; and proportion between flagellomeres: F1 shorter than pedicel, F1-F3 subequal in length in $A$. brevis (Fig. 2c) while F1 longer than pedicel, $\mathrm{F} 1$ longer than F2, F2 subequal to F3 in A. mullensis (Fig. 3e).

Short description. Head yellowish brown, mesosoma and metasoma dark brown; scape, pedicel, F1-F3 yellow, F4-F11 brown; legs yellowish testaceus and veins yellowish brown. Female antennae 13-segmented; F1-F3 smooth and thinner than remaining ones, F4-F11 with rhinaria and club shaped; F1 shorter than pedicel, F1-F3 subequal in width and length, F3 shorter than F4 (Fig. 2c). Male antennae 14-segmented; as female without any flagellomere curved. Pronotum covered by sparse setae, without carinae. Propodeum covered by abundant pubescence with two carinae present, separated by few setae and forming a plate in the lower two-thirds, sides slightly curved. Forewing longer than body; radial cell closed, 2.1 times as long as wide (Fig. 5c). 
Distribution. Mexico (Ferrer-Suay et al. 2013a). New record from Ecuador and Guatemala.

Type material. Deposited in MZLU, examined in Ferrer-Suay et al. (2012c)

Additional examined material (3F). CNCI (1F deposited in UB): "C115- Ecuador: Napo, above Papallacta, ii.1983, 3200m, L. Masner \& M. Sharkey": 1F; "C104- Guatemala: Zacapa, 5 mi. N. San Lorenzo, 24.vi18.viii.1986, J.M. Campbell, FIT": 1F; "C127- Mexico: Chiapas, San Cristobal de las Casas, 7087', 18-19.viii.1969, B.V. Peterson": 1F.

\section{Alloxysta castanea (Hartig, 1841)}

Diagnosis. Alloxysta castanea is mainly characterized having partially open radial cell, pronotal and propodeal carinae present, rhinaria and club shaped begin in F3. It is similar to Alloxysta aurata Belizin, 1968 but they can be differentiated by the relation between F2 and F3: F2 subequal to F3 in $A$. castanea (Fig. $2 \mathrm{~d}$ ) but F2 shorter than F3 in $A$. aurata; and size of radial cell: 2.3 times as long as wide in $A$. castanea (Fig. 5d) while 3.0 times in A. aurata.

Short description. Head yellowish brown, mesosoma brown and metasoma dark brown; scape, pedicel, F1-F2 yellow, F3-F12 yellowish brown; legs yellow and veins yellowish brown. Female antennae 13-segmented; F1-F2 smooth, thinner than remaining flagellomeres, F3-F11 with rhinaria and club shaped; F1 longer than pedicel and F2, F2-F4 subequal in length (Fig. 2d). Male antennae 14-segmented; proportions as female but F1 and F2 slightly curved. Pronotum covered by setae with two strong carinae. Propodeum densely covered with long setae with two carinae forming a plate with slightly curved lateral margins, sparsely pubescent on top. Forewing longer than body; radial cell partially open, 2.4 times as long as wide (Fig. 5d).

Distribution. Mexico (Ferrer-Suay et al. 2013a) and Colombia (Ferrer-Suay et al. 2012b). New record from Chile, Costa Rica, Honduras, Jamaica and Peru.

Type material. Deposited in ZSM, examined in Ferrer-Suay et al. unpubl. results a.

Additional examined material: (8M \& 19F). CNCI (3M \& 5F deposited in UB): "C-452, Chile: Cautin, $1150 \mathrm{~m}$, Conguillio Nat. Park, 45.II.1988 PT, Masner, Araucaria: Nat.”: 1F; “C92- Chile: Nuble, 7.5 km, E. Recinto, $36.359^{\circ} \mathrm{S} 71.579^{\circ} \mathrm{W}, 760 \mathrm{~m}, 4-6 . i .2000$, M.E. Irwin \& E.I. Schlinger, MT in dry riverbed": 2F; "C89- Chile: Cautin, 1150m, Conguillio Nat. Park, 5.ii.1988, L. Masner, Nothofagus/Araucaria forest, sweep": 2M \& 1F; "C102- Chile: Malleco, Cabrerio, 1100m, i.1977, L.E. Peña": 1F; “C84- Costa Rica: Hwy \#2, km 95, 8344’W 9³6'N, iv.85, 3200m, H. Goulet, L. Masner": 1F; "C109- Honduras: Paraiso, Cerro Monserrat, 1800m, 24.v.1994, H. Howden, MT": 1F; "C72- Jamaica: St. Andrews Parish, Hardwar Gap 4000', 16. xii.1972, J. Peck": 1M; “C74Jamaica: St. Thomas Parish, Portland Gap, 5500', 1.viii.1974, S.\&J. Peck”: 1M; “C71- Jamaica: St. Thomas Parish, Whitfield Hall, 4250', 1.viii.1974, S. \& J. Peck": 1M \& 1F; "C73- Jamaica: St. Thomas Parish, Portland Gap, 5500', 17.xii.1972, cloud forest, J. Peck": 1M; "C129- Mexico: Chiapas, Cerro Huitepec, 2750m, 5 km W. San Cristobal de las Casas, 4-25.ix.1992, FIT/PT, R.S. Anderson, cloud forest": 1F; "C130- Peru: Cuzco, Machu Picchu, 1340'S 7040'W, 18.i.1973, J. Helava”: 1F; “C75- Colombia: Putumayo, 2900m, 2.xii.72, $1^{\circ} 10^{\prime} \mathrm{N} 77^{\circ} 15^{\prime} \mathrm{W}$, J. Helava”: 1M. USNM: "Chile: R. ix. PN Nahuebuta, $37^{\circ} 49^{\prime} 42^{\prime}$ "S 7300'39”W, $1138 \mathrm{~m}$, 9-ii2005, J. Heraty meadow \& along stream UCR ATOL C05-005": 1F; "Chile:
R. ix, PN Nahuebutaa, 37 49'30"S 72 58' 24"W, 1168m, 8-24.ii.2005, Malaise trap, meadow \& Nothofagus J. Heraty, UCR ATOL CO5-001": 2F; "Chile: Region IX: Parque Nacional, Nahuelbuto, sweep of Araucaria forest, 8.ii.2005, L. Masner": 1F; “Chile: Región IX: Parque Nacional Puyehue: Anticura: Sendero Repucura: Nothofagus/Chusquea forest, $40^{\circ}$ 39' 53"S 72 10' 02”W, 447m, 17-18.ii.2005": 1F; “Colombia, Boyacá, Arcabuco S.F.F. Iguaque, Cabanas, Mamaramos, 2855m, Malaise4, 16.III1.IV.2000, P. Reina", "Alloxysta det. by ML Buffington, 2012": 1F; "Colombia, Boyacá, SFF Iguaque La Planada m B, 5 42’ N 732 27'W, 2850m, Malaise 28.ii-16.iii.2000, P. Reina leg. M40": 1F; "Colombia, Boyacá, Arcabuco SFF Iguaque, 3450m, Malaise1, 16.iii-2.iv.2000, P. Reina”: 1F; "Colombia, Boyacá, Arcabuco SFF Iguaque, Cabanas Mamaramos, 28550m, Malaise4, 16.iii-1.iv.2000, P. Reina”: 1F; “Colombia, Boyacá, Arcabuco SFF Iguaque, 28550m, Malaise4, Bosque Rastrojo Canon Hamarramas, 28.ii-16.iii.2000, P. Reina": 1M.

\section{Alloxysta citripes (Thomson, 1862)}

Diagnosis. Alloxysta citripes is mainly characterized having partially open radial cell, pronotal carinae present, propodeal carinae present but not protruding, rhinaria and club shaped begin in F4. It is similar to $A$. postica but they can be differentiated by the shape of propodeal carinae: not protruding in $A$. citripes while the carinae are clearly visible and forming a protruding plate in A. postica; and size of radial cell: 2.1 times as long as wide in $A$. citripes (Fig. 5e) but 2.5 times in $A$. postica (Fig. 5u).

Short description. Head, mesosoma brown and metasoma yellowish brown; antennae, legs and veins yellowish. Female antennae 13-segmented; F1-F3 smooth, thinner than remaining flagellomeres, F4-F11 with rhinaria and club shaped; F1 subequal to pedicel and longer than F2, F2-F4 subequal in length (Fig. 2e). Male antennae 14-segmented; F1-F12 with rhinaria and club shaped; pedicel-F3 subequal, F3 slightly shorter than F4. Pronotum with few setae, with two thick carinae clearly visible. Propodeum with many setae and two carinae not protruding, well defined at the first half and forming a plate in the last half. Forewing longer than body; radial cell partially open, 2.1 times as long as wide (Fig. 5e).

Distribution. Widely distributed in the Palaearctic region (Ferrer-Suay et al. 2012a). First record from the Neotropical region (Jamaica).

Type material. Deposited in MZLU, examined in Ferrer-Suay et al. (2013b).

Additional examined material (2M). CNCI (1M deposited in UB): "C72Jamaica: St. Andrews Parish, Hardwar Gap 4000', 16. xii.1972, J. Peck”: 2 M.

\section{Alloxysta costaricensis Ferrer-Suay \& Pujade-Villar, 2011}

Diagnosis. Alloxysta costaricensis is mainly characterized having open radial cell, pronotal and propodeal carinae present, rhinaria and club shaped begin in F4. In the Neotropical region it is similar to $A$. medinae but they can be differentiated by the beginning of rhinaria: in F4 in $A$. costaricensis (Fig. 2f) but in F3 in $A$. medinae (Fig. $3 b$ ); proportion between flagellomeres: F1-F4 subequal in length in $A$. costaricensis (Fig. 2f) while F2 subequal to F3, F3 shorter than F4 in A. medinae (Fig. 3b); and size of radial cell: 3.2 

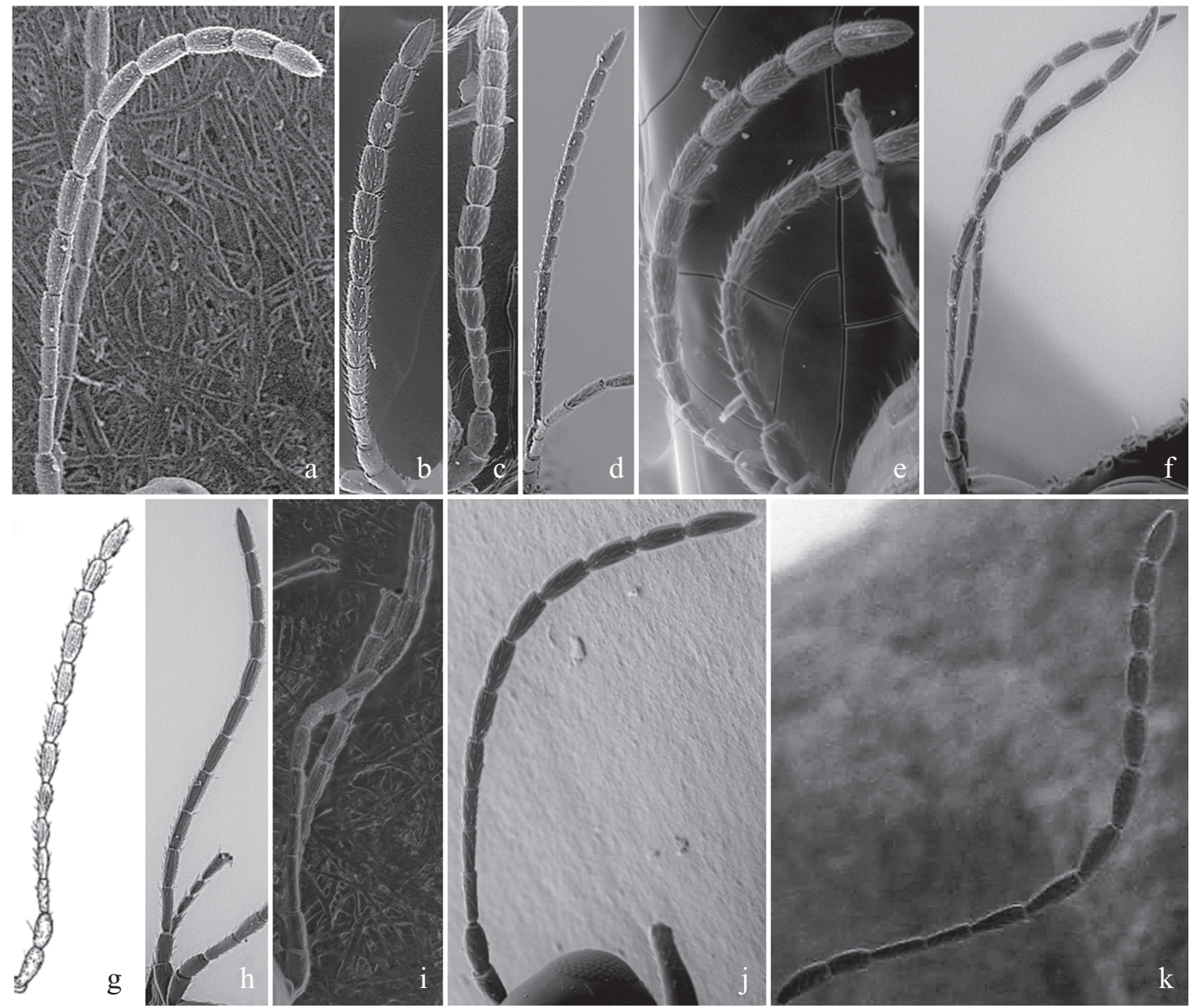

Fig. 2. Types of Alloxysta antenna: a) A. andrewsi; b) A. arcuata; c) A. brevis; d) A. castanea; e) A. citripes; f) A. costaricensis; g) A. desantisi; h) A. evenhuisi; i) A. fracticornis; j) A. fuscicornis; K) A. hansoni.

times as long as wide in $A$. costaricensis (Fig. 5f) but 2.5 times in A. medinae (Fig. $5 \mathrm{~m}$ ).

Short description. Head, mesosoma and metasoma dark brown; scape brown, pedicel, F1-F3 yellowish brown, F4-F12 brown; legs yellowish testaceous and veins brown. Female antennae 13-segmented; F1-F3 smooth, thinner than remaining ones; F4-F11 with rhinaria and club shaped; F1 longer than pedicel, F1 slightly longer than F2, F2-F4 subequal in length (Fig. 2f). Male antennae 14-segmented; F1-F3 smooth, thinner than remaining ones; F4-F12 with rhinaria and club shaped; F1-F3 bowed; F1 longer than pedicel, F1-F4 subequal in length. Pronotum densely covered with long setae at proximal, center and lower corners; distolateral corners almost bare, pronotal carinae clearly distinguishable covered by many setae. Propodeum with two vertical and parallel carinae joining at the base among many pubescence. Forewing longer than body; radial cell open, 3.2 times as long as wide (Fig. 5f).

Distribution. Costa Rica (Ferrer-Suay et al. 2011). New record from Chile.

Type material. Deposited in UCR, examined in Ferrer-Suay et al. (2011). Additional examined material (6M \& 6F). BMNH: "Costa Rica,
Cartago-San Jose, Cerro de la Muerte, 3000m, 2.x.1988, Col. Hanson", "Alloxysta det. N.D.M. Fergusson, 1990": 1M. CNCI_(2M \& 2F deposited in UB): "C89- Chile: Cautin, 1150m, Conguillio Nat. Park, 5.ii.1988, L. Masner, Nothofagus/Araucaria forest, sweep": 1F; "Costa Rica, Hwy. \#2 KM72, 8350'W; 9³8'N, 31.III.85; 2850m. H. Goulet-L. Masner”. $5 \mathrm{M} \&$ \& 4F; “C85- Costa Rica, Hwy \#2, km 95, 834' W 9³6’N, 1.iv.85, 3200m, H. Goulet, L. Masner”: 1F.

\section{Alloxysta desantisi Pujade-Villar \& Díaz, 2002}

Diagnosis. Alloxysta desantisi is mainly characterized having closed radial cell, pronotal and propodeal carinae present, rhinaria begin in F2 and slightly club shaped in F3. It is similar to $A$. xanthocera and $A$. hansoni because the rhinaria and club shaped begin in different flagellomeres. However, they could be differentiated by the beginning of rhinaria: F2 in A. desantisi while $\mathrm{F} 1$ in $A$. xanthochroa and F4 in A. hansoni.

Short description. Head above antennal foramina, antennomeres 4-13, mesosoma and metasoma brown, the latter darker. Head below antennal foramina yellowish-brown. Antennomeres 1-3, wing veins, and legs yellow. Female antennae 13-segmented; F1- smooth, rhinaria begin in F2; F1-F2 


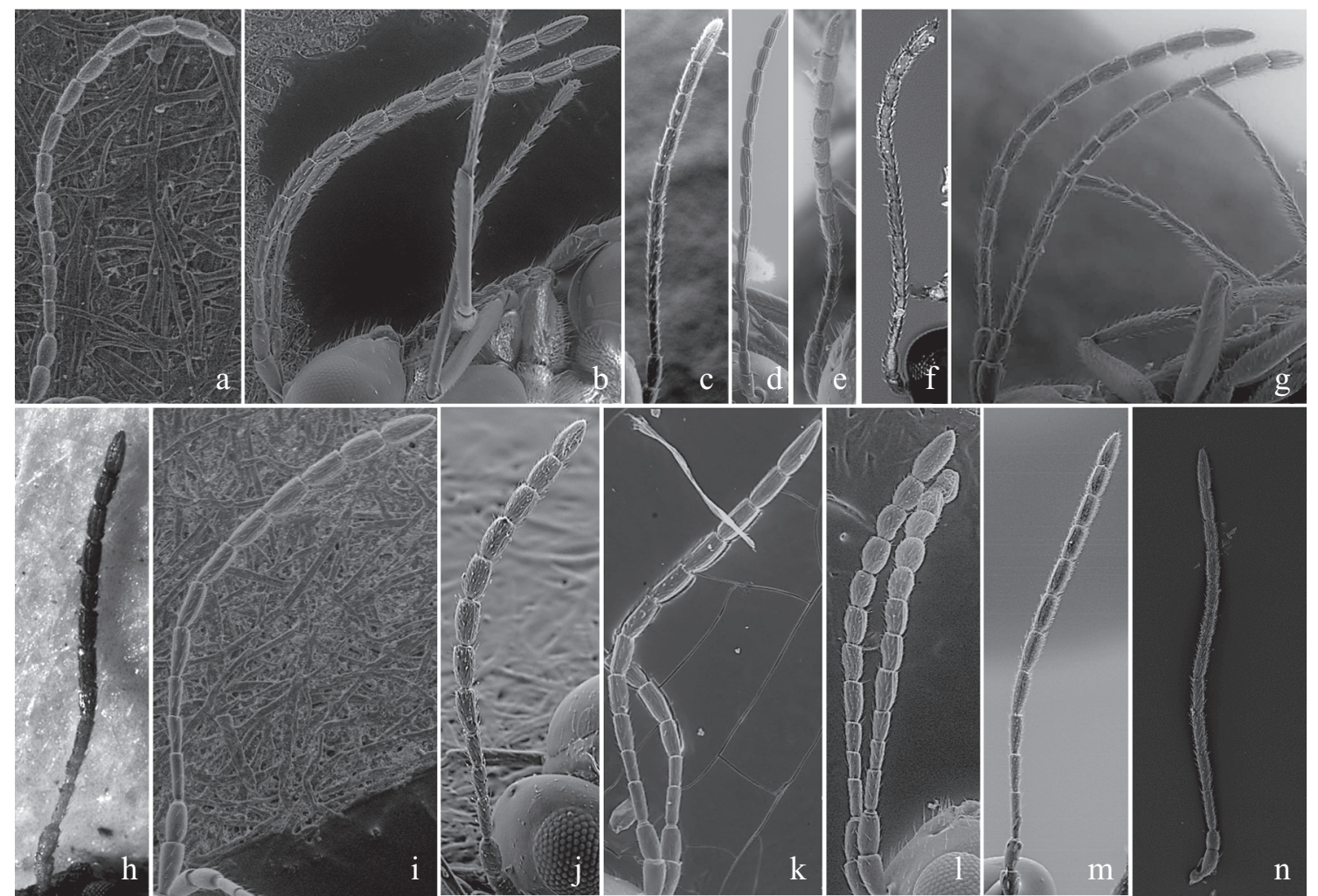

Fig. 3. Types of Alloxysta antenna: a) A. luismii; b) A. medinae; c) A. melanogaster; d) A. mexicana; e) A. mullensis; f) A. nothofagi; g) A. obscurata; h) A. piceomaculata; i) A. pilipennis; j) A. postica; k) A. pusilla; 1) A. sarae; m) A. torresii; n) A. victrix.

thinner than remaining flagellomeres, F3-F11 with rhinaria and club shaped; F1 longer than pedicel, F1-F3 subequal in length (Fig. 2g). Male antennae 14-segmented; as female without any flagellomere curved. Pronotum densely covered with long hairs at proximal margins, nearly bare in the middle of pronotal plate, with two carinae curved, long and noticeable. Propodeum covered by abundant pubescence, propodeal carinae present forming a plate. Forewing longer than body; radial cell closed, 2.2 times as long as wide (Fig. 5g).

Distribution. Argentina, Brazil and Chile (Pujade-Villar et al. 2002).

Type material. Deposited in UB/MLP, examined in Pujade-Villar et al. (2002).

\section{Alloxysta evenhuisi Ferrer-Suay \& Pujade-Villar, 2013}

Diagnosis. Alloxysta evenhuisi is mainly characterized having closed radial cell, pronotal and propodeal carinae present and rhinaria begin in F2 in both male and female. There is no other known Alloxysta species very similar to $A$. evenhuisi.

Short description. Head brown, mesosoma and metasoma dark brown; scape, pedicel and F1 yellow, F2-F12 yellowish brown; legs yellow and veins yellowish brown. Female antennae 13-segmented; F1 smooth, thinner than remaining flagellomeres, F2-F11 with rhinaria and club shaped; F1 longer than pedicel, F1-F4 subequal in length (Fig. 2h). Male antennae 14-segmented; F1 smooth, thinner than remaining flagellomeres, F2-F12 with rhinaria and club shaped; F1 longer than pedicel and F2, F2-F4 subequal in length. Pronotum covered by sparse setae, with two thick carinae present clearly visible. Propodeum covered by many setae; two propodeal carinae forming a plate, with few setae on the upper part and strongly curved sides. Forewing longer than body; radial cell closed, 2.3 times as long as wide in female and 2.6 times as long as wide in male (Fig. 5h).

Distribution. Mexico (Ferrer-Suay et al. 2013a). New record from Chile, Colombia, Ecuador and Guatemala.

Type material. Deposited in UAEM, examined in Ferrer-Suay et al. (2013a).

Additional examined material ( $2 \mathrm{M} \& 5 \mathrm{~F})$. CNCI ( $1 \mathrm{M} \& 1 \mathrm{~F}$ deposited in UB): "C118- Ecuador: Napo, Baeza, 1900m, 9.ii.1983, L. Masner \& M. Sharkey": 2F; "C106- Guatemala: Sacatepequez, above Antigua Guatemala, Volcán Agua, 1700m, 23.xi.1986, M. Sharkey, sweep": 2M;. USNM: “Chile: R. ix. PN Nahuebuta, 37 49' 42"S 7300' 39"W, 1138m, 9-ii-2005, J. Heraty meadow \& along stream UCR ATOL C05-005": 1F; “Chile: R. ix, PN Nahuebutaa, $37^{\circ} 49^{\prime} 30^{\prime}$ "S $72^{\circ} 58^{\prime} 24^{\prime \prime}$, $1168 \mathrm{~m}, 8-$ 24.ii.2005, Malaise trap, meadow \& Nothofagus J. Heraty, UCR ATOL CO5-001": 1F; "Colombia: Santander, PNN Tamá, Mun. Toledo, Vda. La Camacha, Pozo Negro", “7 $7^{\circ} 21^{\prime} \mathrm{N} 72^{\circ} 28^{\prime} \mathrm{W}, 2213 \mathrm{~m}$, Malaise 23.x2.xi.2003, C. Leal leg. M4029": 1F.

\section{Alloxysta fracticornis (Thomson, 1862)}

Diagnosis. Alloxysta fracticornis is mainly characterized having closed radial cell, pronotal carinae absent, propodeal 


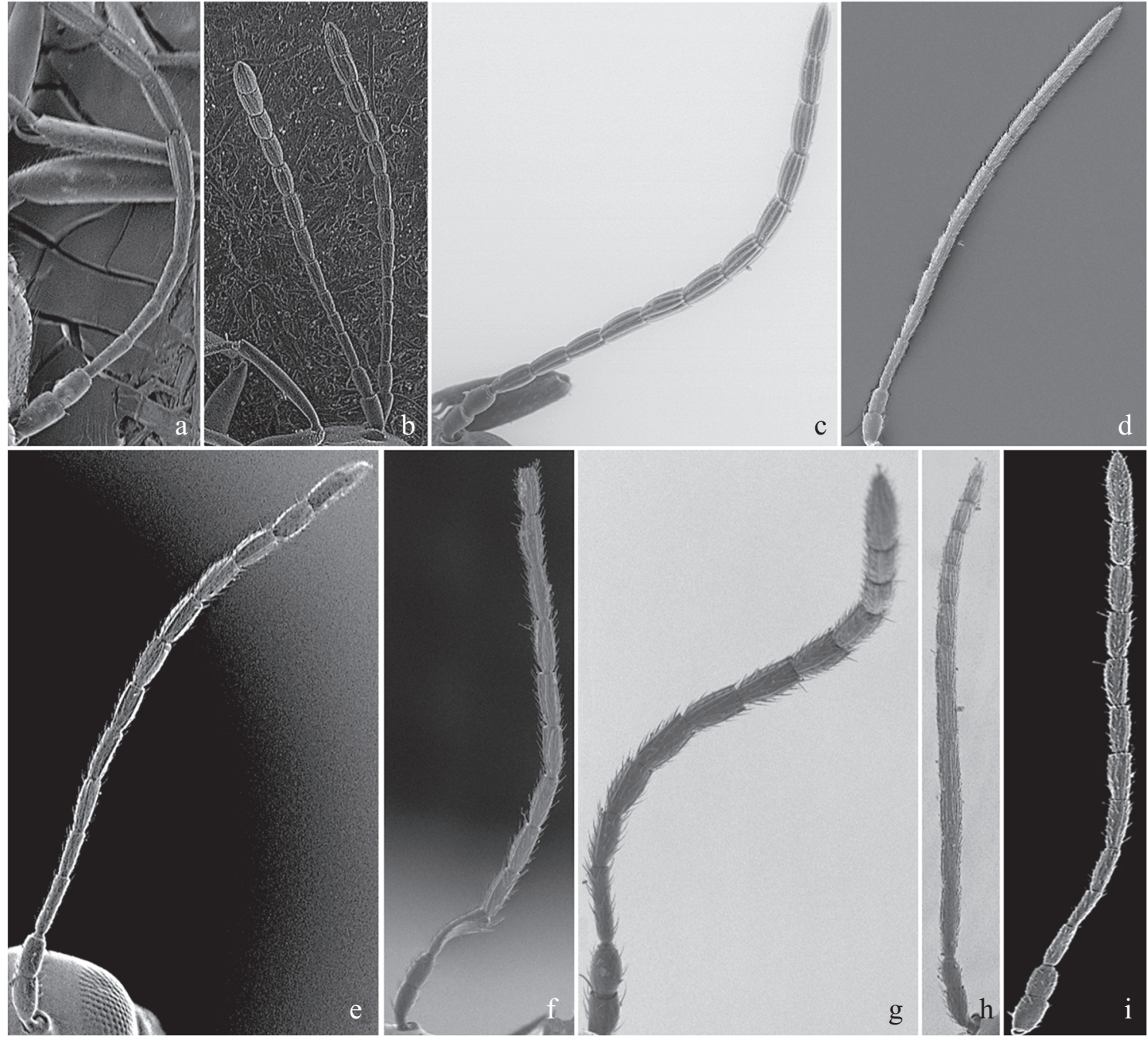

Fig. 4. Apocharips, Dilyta and Phaenoglyphis antenna: a) A. angelicae; b) A. hansoni; c) D. paretasmartinezi; d) P. americana; e) P. calverti; f) P. falcata; g) P. stenos; h) P. stricta; i) P. villosa.

carinae present, rhinaria and club shaped begin in F3. It is similar to $A$. mullensis but they can be differentiated by the relation between $\mathrm{F} 1$ and pedicel: $\mathrm{F} 1$ longer than pedicel in $A$. fracticornis (Fig. 2i) while $\mathrm{F} 1$ subequal to pedicel in $A$. mullensis (Fig. 3e); F1-F3 subequal in length in A. fracticornis (Fig. 2i) but F1 longer than F2 and F2 subequal to F3 in $A$. mullensis (Fig. 3e); and F3 curved in A. fracticornis male but without any flagellomere curved in $A$. mullensis male.

Short description. Head yellow, mesosoma and metasoma brown; antennae yellow, darkening towards the end; legs yellow and veins yellowish. Female antennae 13-segmented; F1F2 smooth, thinner than remaining flagellomeres, F3-F11 with rhinaria and club shaped; F1 longer than pedicel, F1-F3 subequal in length, F3 shorter than F4 (Fig. 2i). Male antennae 14-segmented; F1-F2 smooth, thinner than remaining flagellomeres, F3-F12 with rhinaria and club shaped; F1 longer than pedicel, F1-F3 subequal in length, F3 curved, F3 longer than F4. Pronotum covered by setae, without carinae visible. Propodeum with few setae, with two straight and parallel carinae joining at the base. Forewing longer than body; radial cell closed, 2.2 times as long as wide (Fig. 5i).

Distribution. Palaearctic (Ferrer-Suay et al. 2012a). First record from Neotropical region (Ecuador).

Type material. Deposited in MZLU, examined in Ferrer-Suay et al. (2013b, in press).

Additional examined material (1M). CNCI: "C115- Ecuador: Napo, above Papallacta, ii.1983, 3200m, L. Masner \& M. Sharkey”: 1M.

\section{Alloxysta fuscicornis (Hartig, 1841)}

Diagnosis. Alloxysta fuscicornis is mainly characterized having closed radial cell, pronotal carinae present, propodeal carinae absent, rhinaria and club shaped usually begin in F4 (sometimes in F3). It is similar to A. circumscripta (Hartig, 1841 ) but they can be differentiated by the proportion between flagellomeres: F1 longer than F2, F2 subequal to F3 in A. fuscicornis (Fig. 2j) while F1 subequal to F2, F2 shorter or subequal to $\mathrm{F} 3$ in $A$. circumscripta; and size of radial cell: 2.7 times as long as wide in $A$. fuscicornis (Fig. 5j) but 2.5 in A. circumscripta. 
Short description. Head, mesosoma and metasoma brown; scape, pedicel, F1 and F2 yellow and F3-F12 yellowish brown; legs yellow and veins brown. Female antennae 13segmented; F1-F3 smooth and thinner than remaining ones, F4-F11 with rhinaria and club shaped; F1 longer than pedicel and F2, F2 longer than F3, F3 shorter than F4 (Fig. 2j). Male antennae 14-segmented; with the same proportion as female but F1-F3 bowed (F1 slightly bowed while F2 and F3 clearly bowed). Pronotum covered by setae with two carinae present clearly visible. Propodeum also with abundant setae and without carinae. Forewing longer than body; radial cell closed, 2.7 times as long as wide (Fig. 5j).

Distribution. Cosmopolitan (Ferrer-Suay et al. 2012a). Argentina (de Santis 1937; Pujade-Villar et al. 2002; Berta et al. 2002), Brazil (Betini 1975; Betini 1976; Lazzari 1985; Tavares 1991; Cividanes 2002; Pujade-Villar et al. 2002; Vaz et al. 2004), Chile (Pujade-Villar et al. 2002) and Colombia (Pujade-Villar et al. 2010).

Type material. Deposited in ZSM, examined in Ferrer-Suay et al. (in press a)

Additional examined material (3M \& 5F). BMNH: "Ex. Aphidius ervi", "Dr. F. Zunigo La Cruz, Chile, Rec. 10.v.77": 1M; "Brasil: Paraná: Piraquara: 1-vii-1992: M. Mello", "K-J. Hedqvist coll: BMNH-ENT-201127": 2M. CNCI (2F deposited in UB): "Chile: Malleco, Parque Nacional Tolhuaca, 900m, 2.III.78, T. Cekalovic": 1F; "C94- Chile: S. ColinaSantiago, El Partezuelo, xi.1978": 1F; "C99- Chile: 7 km N. Los Vilos, Choapa, $31.8508^{\circ} \mathrm{S} 70.4952^{\circ} \mathrm{W}, 215 \mathrm{~m}, 5 . x i .1997$, M.E. Irwin, E.I. Schlinger, coastal dunes": 1F; "C95- Chile: Santiago, Quebrada la Plata, 5 km W La Rinconada de Maipú, $33.4984^{\circ} \mathrm{S} 70.9042^{\circ} \mathrm{W}, 400 \mathrm{~m}, 31 . \mathrm{x}-$ 10.xi.1997, G. Burnis, M.E. Irwin, MT": 1F; "C96- Chile: Quillota, Palma de Ocoa, Campanas Nat. Park, $32.9324^{\circ} \mathrm{S} 71.0781^{\circ} \mathrm{W}, 13-20 . x i .1997$, M.E. Irwin E.I. Schlinger, 215m, MT in hillside draw": 1F.

\section{Alloxysta hansoni Pujade-Villar, 2011}

Diagnosis. Alloxysta hansoni is mainly characterized having closed radial cell, pronotal and propodeal carinae present, club shape and rhinaria begin in different flagellomeres. It is similar to $A$. xanthocera (Thomson, 1862) but they can be differentiated by the beginning of rhinaria and club shape in female: club shape begin in F3 and rhinaria begin in F4 in $A$. hansoni (Fig. 2k) while club shape begin in F2 and rhinaria begin in F1 in A. xanthocera; and apex of scutellum with a thick carinae in $A$. hansoni but without carinae in A. xanthocera.

Short description. Head brown or yellowish brown, mesosoma and metasoma dark brown; scape, pedicel and F1 dark yellow or yellowish brown, F2-F12 brown; legs dark yellow and veins brown. Female antennae 13-segmented; F1-F2 thinner than remaining ones, F3-F11 with club shaped, rhinaria begin in F4; F1 longer than pedicel and F2, F2 shorter than F3, F3 shorter than F4 (Fig. 2k). Male antennae 14-segmented; F1 smooth, thinner than remaining ones; F2-F12 with rhinaria and club shaped; F1 slightly curved; F1 longer than pedicel and F2, F2 subequal to F3, F3 shorter than F4. Pronotum densely covered with long setae, glabrous or with very few setae at distolateral corners; pronotal carinae long and thick covered by many setae. Carinae of propodeum defined in the anterior
$2 / 3$ separated by a space densely pubescent, forming a plate on the lower $1 / 3$, slightly curved sides, having several carinae at the base of the plate. Forewing longer than body; radial cell closed, 2.4 times as long as wide in both sexes (Fig. 5k).

Distribution. Costa Rica (Ferrer-Suay et al. 2011). (2011)

Type material. Deposited in UCR, examined in Ferrer-Suay et al.

\section{Alloxysta luismii Ferrer-Suay, 2011}

Diagnosis. Alloxysta luismii is mainly characterized having a partially open radial cell, pronotal and propodeal carinae present, rhinaria and club shape begin in different flagellomeres. There is no other known Alloxysta species closely related present in the Neotropical region.

Short description. Head, mesosoma and metasoma light brown, the bottom of the head and metasoma yellowish; scape, pedicel and F1 yellow, the rest of flagellomeres brown gradually darkening towards the end; legs dark yellow and veins brown. Male antennae 14-segmented; F1 thinner, F2-F12 with club shaped; F1-F2 smooth, F3-F12 with rhinaria; Pedicel-F3 subequal in length, F3 shorter than F4 (Fig. 3a). Pronotum densely covered by long setae, glabrous or with very few setae at distolateral corners; pronotal carinae thick, clearly visible. Carinae of propodeum defined in the anterior $2 / 3$ separated by a space densely pubescent, forming a plate on the lower $1 /$ 3 , curved side, having several carinae at the base of the plate. Forewing longer than body, radial cell partially open; 2.3 times as long as wide in both sexes (Fig. 51).

Female unknown.

Distribution. Costa Rica (Ferrer-Suay et al. 2011). (2011).

Type material. Deposited in UCR, examined in Ferrer-Suay et al.

\section{Alloxysta medinae Ferrer-Suay \& Pujade-Villar, 2012}

Diagnosis. Alloxysta medinae is mainly characterized having open radial cell, pronotal and propodeal carinae present, rhinaria and club shaped begin in F3. In the Neotropical region it is similar to $A$. costaricensis but they can be differentiated by the beginning of rhinaria: in F3 in A. medinae (Fig. 3b) but in F4 in A. costaricensis (Fig. 2f); proportion between flagellomeres: F2 subequal to F3, F3 shorter than $\mathrm{F} 4$ in A. medinae (Fig. 3b) while F1-F4 subequal in length in A. costaricensis (Fig. 2f); and size of radial cell: 2.5 times as long as wide in A. medinae (Fig. 5m) but 3.2 times in $A$. costaricensis (Fig. 5f).

Short description. Head, mesosoma and metasoma dark brown; scape yellowish brown, pedicel-F2 dark yellow, F3F12 yellowish brown; legs yellow and veins yellowish brown. Female antennae 13-segmented; F1 and F2 smooth and thinner than remaining ones, F3-F11 with rhinaria and club shaped; F1 longer than pedicel and F2, F2 subequal to F3, F3 shorter than F4 (Fig. 3b). Male antennae 14-segmented; $\mathrm{F} 1$ and F2 smooth and thinner than remaining ones, F3-F12 


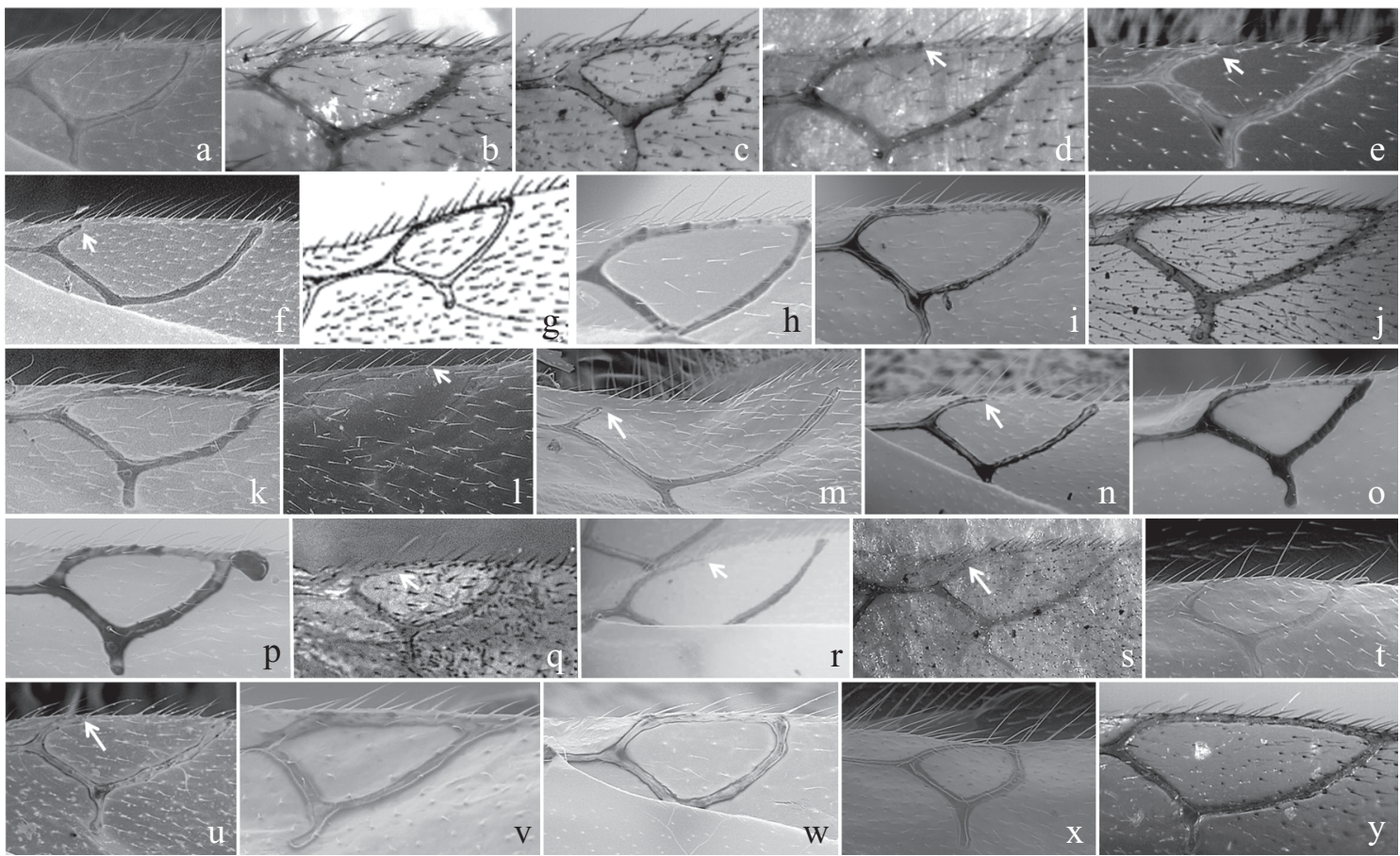

Fig. 5. Types of Alloxysta radial cell: a) A. andrewsi; b) A. arcuata; c) A. brevis; d) A. castanea; e) A. citripes; f) A. costaricensis; g) A. desantisi; h) A. evenhuisi; i) A. fracticornis; j) A. fuscicornis; K) A. hansoni; 1) A. luismii; m) A. medinae; n) A. melanogaster; o) A. mexicana; p) A. mullensis; q) A. nothofagi; r) A. obscurata; s) A. piceomaculata; t) A. pilipennis; u) A. postica; v) A. pusilla; w) A. sarae; x) A. torresii; y) A. victrix.

with rhinaria and club shaped; F1 longer than pedicel and F2, F2 subequal to F3, F3 shorter than F4. Pronotum covered by sparse setae, being more abundant on anterior margin; without carinae present. Propodeum with abundant pubescence; two propodeal carinae well-defined separated by setae on the first third and forming a plate with few carinae on the last two thirds. Forewing longer than body; radial cell open, 2.5 times as long as wide (Fig. $5 \mathrm{~m}$ ).

Distribution. Colombia (Ferrer-Suay et al. 2012b). New record from Costa Rica, Ecuador, Guatemala, Mexico and Venezuela.

Type material. Deposited in IAvH, examined in Ferrer-Suay et al. (2012b).

Additional examined material (13M \& 50F). CNCI (4M \& 10F deposited in UB): “C81- Colombia: Valle, above Saladido, 6500', 8.iv.1971, Eberhard \& Garcia": 2F; “C79- Colombia: Caldas, 5.iv.1974, 5'5'N 25⒉'W, J. Helava": 1M; "C78- Colombia: Valle, above Saladito, 6500', roadside low 2nd growth forest, 8.iv.1971, W. Eberhard, L. Garcia": 1F; "C77- Colombia: 11 km E Calarcá, Quindio, 7000', iii.1974, S.\&J. Peck": 1M \& 1F; "C83- Costa Rica: Cerro de la Muerte, Arroyo Muerte, 3200m, 31.iii.85, L. Masner, sweeping”: 2F; “C82- Costa Rica: Hwy \#2, km 95, 8344’W 9³6’N, 3-13.iv.85, 3200m, H. Goulet, L. Masner": 3F; "C86- Costa Rica: Hwy \#2, km 72, 2850m, 31.iii.85, L. Masner, oak cloud forest, sweep": 5M \& 2F; “C84- Costa Rica: Hwy \#2, km 95, 8344'W 9³6’ N, iv.85, 3200m, H. Goulet, L. Masner": 1F; “C113- Ecuador: Napo, Sierra Azul, 2300m, $0.67^{\circ} \mathrm{S}$ 77.92W, 9-19.ii.1996, P. Hibbs, MT": 7F; "C110- Ecuador: Napo, Sierra Azul, 2300m, $0.67^{\circ} \mathrm{S} 77.92^{\circ} \mathrm{W}$, 21.iv-6.vi.1996, P. Hibbs, MT": 2M \& 7F; "C114- Ecuador: Napo Sierra Azul, 2300m, 21-22.iv.1996, P. Hibbs, YPT (18)": 1M; “C112- Ecuador: Napo, Sierra Azul, $2300 \mathrm{~m}, 0.67^{\circ} \mathrm{S} 77.92^{\circ} \mathrm{W}$, 17.ii-26.iii.1996, P. Hibbs, MT": 7F; "C111- Ecuador: Napo, Sierra Azul, 2300m, $0.67^{\circ} \mathrm{S} 77.92^{\circ} \mathrm{W}, 17$. ii-8.iii.1996, P. Hibbs, MT": 5F; "C115- Ecuador: Napo, above Papallacta, ii.1983, 3200m, L. Masner \& M. Sharkey”:
1F; "C106- Guatemala: Sacatepequez, above Antigua Guatemala, Volcán Agua, 1700m, 23.xi.1986, M. Sharkey, sweep": 1M; "C126- Mexico: Guerrero, 10.3 km SW Filo de Caballo, 2700m, 17.vii.1992, R.S. Anderson, oak/pine/fir forest": 2F; "C121- Mexico: Oaxaca, Llano de las Flores, 15 mi, NE Ixtlán de Juárez, 21.vii.1985, J. Woolley, G. Zolnerowich": 2M; "C123- Venezuela: Trujillo, 2000-3000m, 26.viii-1.ix.1992, L. Masner, carnet": 1F; USNM: "Colombia: Near Bogotá, Parmo Monserraté, 3200m, Sept. 2.1989, H. Sturm, 91-1843", "Ex. Espeletiapsis Corymbosa (H. + B.)", "Alloxysta?? det. A. S. Menke 91": 1F; "Colombia: Cundinamarca, PNN Chingaza Valle del Freylejon, $4^{\circ} 31^{\prime} \mathrm{N} 73^{\circ} 45^{\prime} \mathrm{N}$, 20-xii-2000, 5-i2001, L. Cifuentes, 3170m, Malaise trap M1220": 1F; "Colombia, Cundinamarca, PNN Chingaza Bosque Palacio, $4^{\circ} 31^{\prime} \mathrm{N} 73^{\circ} 45^{\prime} \mathrm{W}, 2930 \mathrm{~m}$, Malaise, 17.i-4.ii.2001, L. Cifuentes leg., M1258": 1F; "Colombia, Boyacá, Arcabuco SFF Iguaque, 3100m, Malaise1, 25.ii-16.iii.2000, P. Reina": 1F; "Colombia, Boyacá, Arcabuco SFF Iguaque, 2820m, Malaise7, 28.ii17.iii.2000, P. Reina": 1F; "Colombia, Boyacá, Arcabuco SFF Iguaque, 2795m, Malaise8, 28.ii-17.iii.2000, P. Reina": 1F; "Colombia, Boyacá, Arcabuco SFF Iguaque, Bosque AHO, andino, 2975m, Malaise4, 16.iii1.iv.2000, P. Reina": 1F; "Ecuador: Napo Prov. Yanayacu Biological Sta., $0^{\circ}$ 35.9'S $77^{\circ} 32.5^{\prime} \mathrm{W}, 2163 \mathrm{~m}$, MT 5-12.vi.2006", “J.B. Whitifield, J.J. Rodfrigues, D.C. Arias Penna, C.C. Gunter": 1F.

\section{Alloxysta melanogaster (Hartig, 1840)}

Diagnosis. Alloxysta melanogaster is mainly characterized having partially open radial cell, pronotal and propodeal carinae present, rhinaria and club shaped begin in F3. It is similar to $A$. castanea but they can be differentiated by the relation between pedicel-F3 in female: pedicel-F3 subequal in A. melanogaster (Fig. 3c) while F1 longer than F2 and F2 subequal to $\mathrm{F} 3$ in $A$. castanea (Fig. $2 \mathrm{~d}$ ); and size of radial cell: 2.0 times as long as wide in $A$. melanogaster (Fig. 5n) but 2.3 in $A$. castanea (Fig. 5d). 

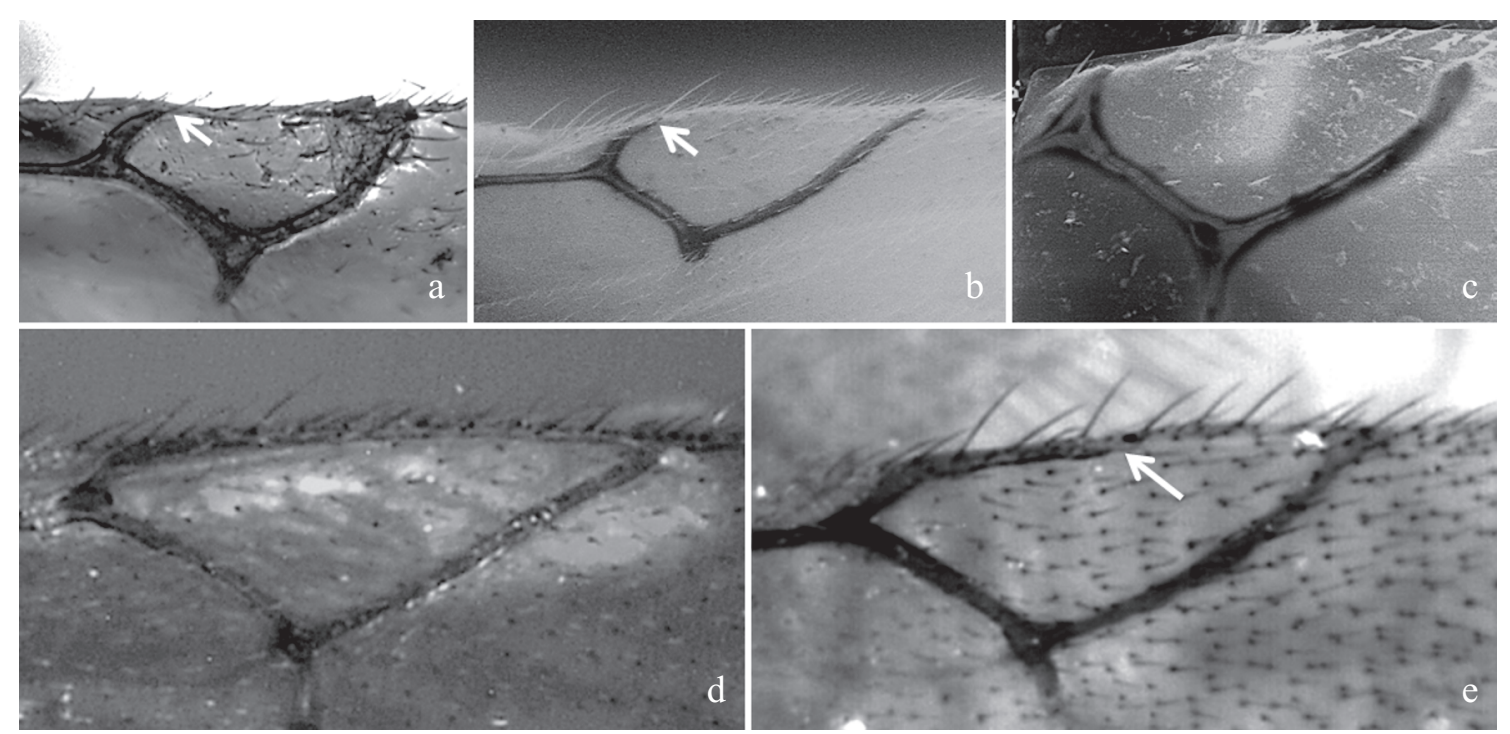

Fig. 6. Apocharips, Dilyta and Phaenoglyphis radial cell: a) A. angelicae; b) A. hansoni; c) D. paretasmartinezi; d) P. americana; e) P. villosa.

Short description. Head yellow, mesosoma and metasoma yellowish brown; antennae yellow with last flagellomeres brown; legs and veins yellow. Female antennae 13-segmented; F1-F2 smooth, thinner than remaining ones, F3-F11 with rhinaria and club shaped; F1 subequal to pedicel, F1 longer than F2, F2 subequal to F3, F4 longer than F3 (Fig. 3c). Male antennae 14segmented; F1 smooth, thinner than remaining ones, F2-F12 with rhinaria and club shaped; F1 longer than pedicel and F2, F2-F4 subequal in length. Pronotum densely covered by long setae, with two carinae present. Propodeum densely setose, carinae present forming a plate with margins very slightly curved and few setae on top. Forewing longer than body; radial cell partially open, 2.3 times as long as wide (Fig. 5n).

Distribution. Widely distributed in the Palaearctic region (Ferrer-Suay et al. 2012a). First record from the Neotropical region (Chile).

Type material. Deposited in ZSM, examined in Ferrer-Suay et al. (in press a).

Additional examined material $(2 \mathrm{M} \& 2 \mathrm{~F})$. CNCI (1M deposited in UB): “C99- Chile: $7 \mathrm{~km} \mathrm{~N}$. Los Vilos, Choapa, $31.8508^{\circ} \mathrm{S} 70.4952^{\circ} \mathrm{W}$, 215m, 5.xi.1997, M.E. Irwin, E.I. Schlinger, coastal dunes": 2M \& 1F. USNM: “Chile: Region IX, Parque Nacional Vista Hermosa, 38 45' $08^{\circ}$ "S 71 $37^{\circ}$ '24”W, 816m, YPT 22-24.ii.2005, UCR Atol Co5-036": 1F.

\section{Alloxysta mexicana Ferrer-Suay \& Pujade-Villar, 2013}

Diagnosis. Alloxysta mexicana is mainly characterized having closed radial cell, pronotal carinae absent, propodeal carinae present, rhinaria and club shaped begin in F1. There is no other known Alloxysta species very similar to A. mexicana.

Short description. Head, mesosoma and metasoma dark brown; F1 and F2 dark yellow, scape, pedicel and F3-F12 yellowish brown; legs yellow and veins yellowish brown. Male antennae 14-segmented; rhinaria and club shaped begin in the first third of F1; F1 longer than pedicel and F2, F2 longer than F3, F3 subequal to F4 (Fig. 3d). Pronotum cove- red by sparse setae being more abundant on anterior margin, without carinae present. Propodeum covered by many setae; two propodeal carinae present, well defined in the first two thirds and joining in the last third. Forewing longer than body; radial cell closed, 2.1 times as long as wide (Fig. 5o).

Female unknown.

Distribution. Mexico (Ferrer-Suay et al. 2013a).

Type material. Deposited in UAEM, Morelos, examined in FerrerSuay et al. (2013a).

\section{Alloxysta mullensis (Cameron, 1883)}

Diagnosis. Alloxysta mullensis is mainly characterized having closed radial cell, pronotal carinae absent, propodeal carinae present, rhinaria and club shaped begin in F4. It is similar to $A$. fracticornis but they can be differentiated by the relation between F1 and pedicel: F1 subequal to pedicel in A. mullensis (Fig. 3e) while F1 longer than pedicel in A. fracticornis (Fig. 2i); proportion between flagellomeres: F1 longer than F2 and F2 subequal to F3 in A. mullensis female (Fig. 3e) but F1-F3 subequal in length in $A$. fracticornis female (Fig. 2i); and shape of flagellomeres: without any flagellomere curved in $A$. mullensis male but F3 curved in A. fracticornis male.

Short description. Head brown, mesosoma and metasoma dark brown; scape, pedicel and F1-F3 dark yellow, F4-F12 yellowish brown; legs and veins yellow. Female antennae 13segmented; F1-F3 smooth and thinner than remaining ones, F4-F11 with rhinaria and club shaped; pedicel subequal to F1, F1 longer than F2, F2 subequal to F3, F3 shorter than F4 (Fig. 3e). Male antennae 14-segmented; as female without any flagellomere curved. Pronotum covered by sparse setae, without carinae present. Propodeum with abundant pubescence, two carinae present forming a plate with sides slightly curved. Forewing longer than body; radial cell closed, 2.2 times as long as wide (Fig. 5p). 

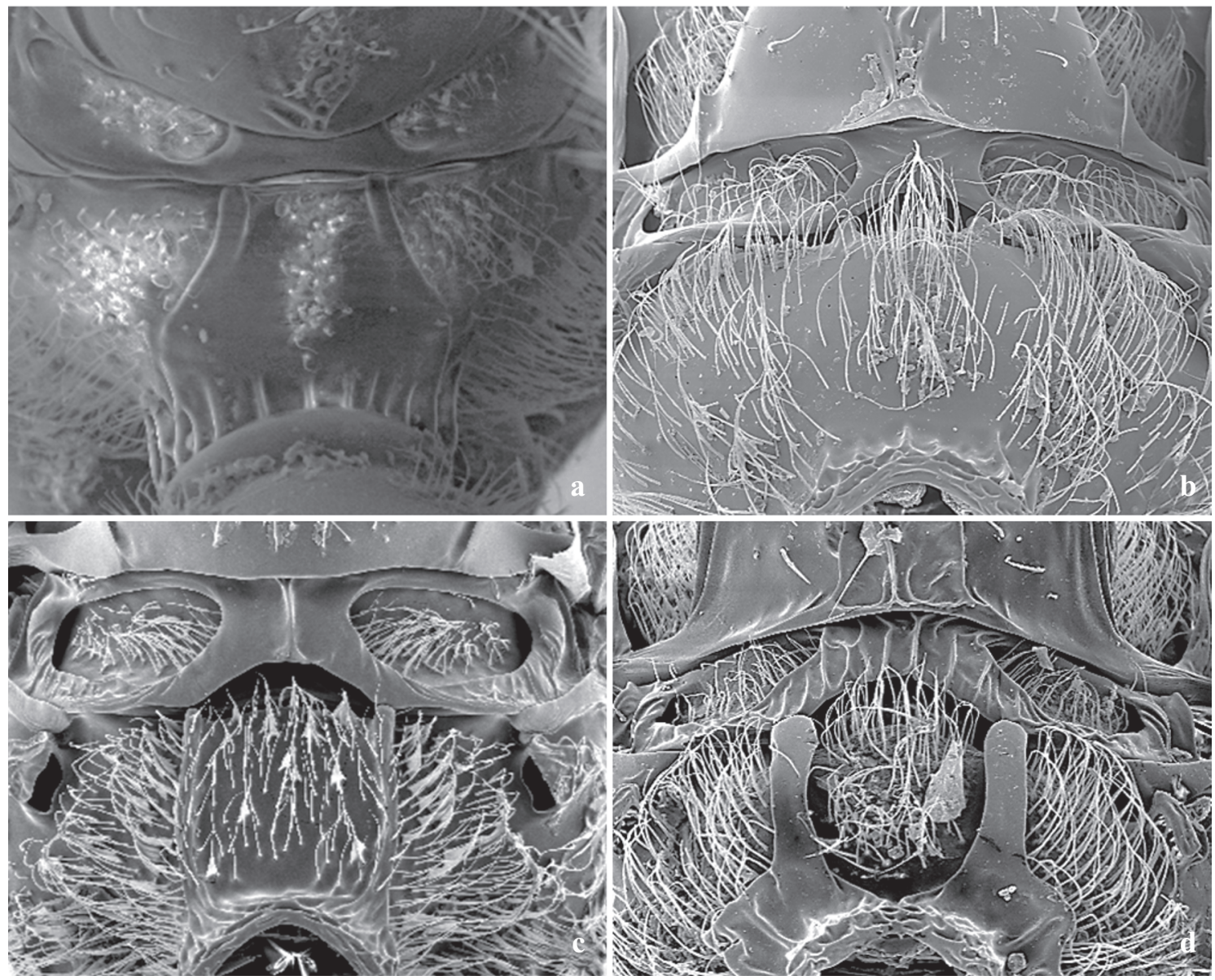

Fig. 7. Types of propodeum in Charipinae: a) A. arcuata; b) A. victrix; c) P. americana; d) A. trapezoidea.

Distribution. Widely distributed in the Palaearctic region (Ferrer-Suay et al. 2012a). Colombia (Ferrer-Suay et al. 2012b). New record from Brazil and Ecuador.

Type material. Deposited in BMNH, examined in FerrerSuay et al. (2012c).

Additional examined material ( $1 \mathrm{M} \& 8 \mathrm{~F})$. CNCI $(2 \mathrm{~F}$ deposited in UB): "C65- Brazil: Minas Gerais, Poços de Caldas, vii.1972, sweeping, M. Alvarenga": 1F; “C79- Colombia: Caldas, 5.iv.1974, $5^{\circ} 5^{\prime} \mathrm{N} 25^{\circ} 25^{\prime} \mathrm{W}$, J. Helava": 2F; "C115- Ecuador: Napo, above Papallacta, ii.1983, 3200m, L. Masner \& M. Sharkey": 1M \& 2F. USNM: "Colombia, Cundinamarca, PNN Sumapaz, Bocatoma Cerro el zapato, $4^{\circ} 14^{\prime} \mathrm{N} 74^{\circ} 12^{\prime} \mathrm{W}, 3560 \mathrm{~m}$ ", "Pantrap 6-7.xi.2002, A. Patiño, H. Angel \& D. Arias leg, M798": 1F; "Colombia: Cundinamarca, PNN Chingaza Valle del Freylejon, $4^{\circ} 31^{\prime} \mathrm{N}$ $73^{\circ} 45^{\prime} \mathrm{N}$, 20-xii-2000, 5-i-2001, L. Cifuentes, 3170m, Malaise trap M1220": 1F; "Colombia, Boyacá, Arcabuco SFF Iguaque, 2980m, Malaise9, 17.iii-1.iv.2000, P. Reina”: 1F.

\section{Alloxysta centroamericana Ferrer-Suay \& Pujade-Villar sp. nov.}

(Fig. 9)

Diagnosis. Alloxysta centroamericana is mainly characterized having completely open radial cell, pronotal carinae present, propodeal carinae absent, F1 and F2 curved. It is similar to Alloxysta vandenboschi but they can be differenti- ated by the curved flagellomeres: $\mathrm{F} 1$ and $\mathrm{F} 2$ curved in $A$. centroamericana (Fig. 9d) but F2 and F3 curved in $A$. vandenboschi; and size of radial cell: 4.1 times as long as wide in A. centroamericana (Fig. 9b) while 2.9 times in $A$. vandenboschi.

Description. Male: Coloration. Head, mesosoma and metasoma yellowish brown. Antenna yellowish, darkening towards the end. Legs yellow and veins yellowish brown.

Head. Transversally ovate, smooth and shiny, slightly wider than high in front view. Setae below and between toruli, few scattered setae above toruli. Scattered setae on vertex and many setae on face. Transfacial line 1.1 times the height of compound eye. Malar space 0.4 times the height of compound eye. Antenna. 14-segmented, filiform. All antennomeres covered with sparse setae. F1-F12 with rhinaria and club shaped. Antennal formula: 3.0 (1.9); 4.5 (1.2); 3.5 (1.2); 3.5 (1.2); 3.8 (1.3); F4-F12 subequal in length, width and shape (Fig. 9d). Mesosoma. Pronotum covered by sparse setae, being nearly absent in the distolateral corners, with two carinae present (Fig. 9c). Mesoscutum smooth and shiny, round in dorsal view with few scattered setae. Scutellum smooth and shiny with scattered setae, more abundant on apex of scutellum. Propodeum covered by abundant setae, without carinae present, only visible two peaks at the top and few 

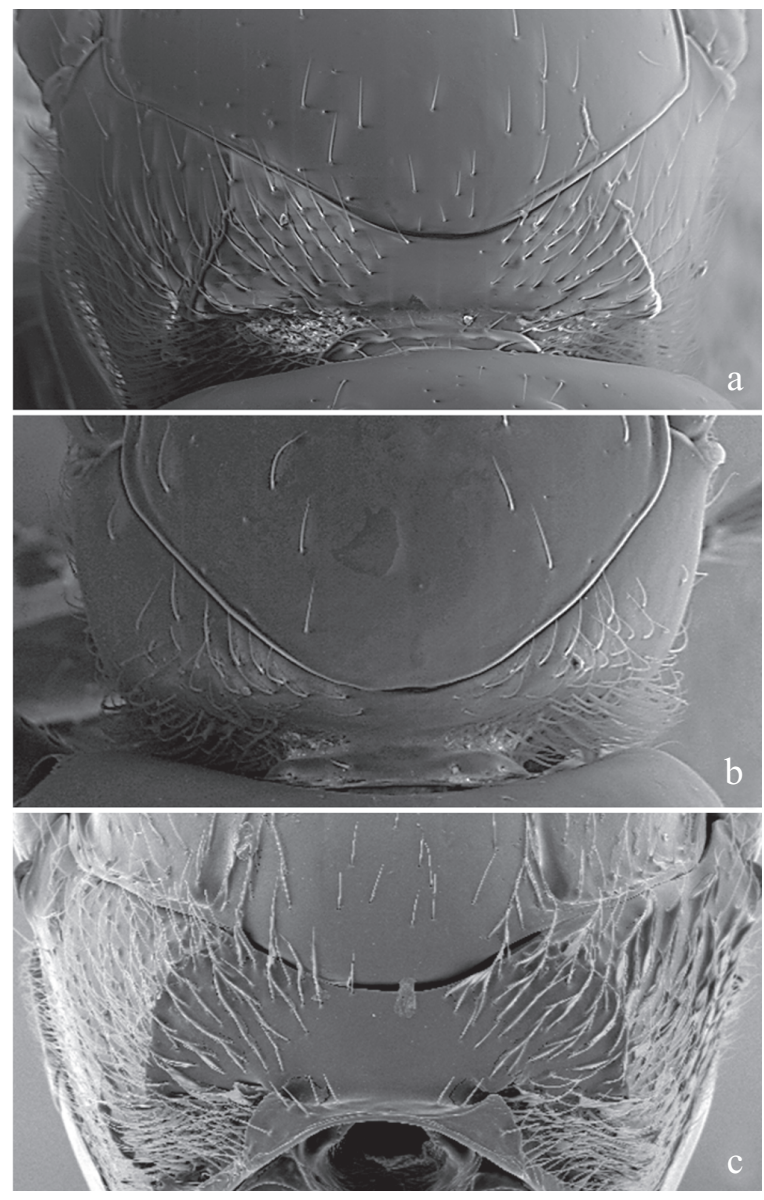

Fig. 8. Types of pronotum of Charipinae: a) A. arcuata; b) A. brevis; c) $P$. americana.

carinae of the bottom of the propodeum (Fig. 9f). Forewing. Longer than body, 1.6 times as long as mesosoma and metasoma together. Covered with dense pubescence; marginal setae present (Fig. 9a). Open radial cell, 4.1 times as long as wide. R1 short and curved; Rs long and also curved (Fig. 9b). Metasoma. Anterior part with an incomplete ring of setae, glabrous at centre, wider laterally. Metasoma smooth and shiny, T3 and T4 clearly distinguished.

Female: unknown.

Etimology. The new species is named after the biogeographical region where it was first found.

Distribution. Guatemala and Mexico.

Type material (3M). Holotype M with the following labels: "Mexico: Estado Hidalgo, Rancho Santa Elena, 10Km, WSW Acatlan, 1417.III.2005, 2487m, $20^{\circ} 7.97^{\prime} \mathrm{N} 98^{\circ} 31.42^{\prime}$ W, S.L. Winterton”. Paratypes (2M) with the following labels: "C106- Guatemala: Sacatepequez, above Antigua Guatemala, Volcán Agua, 1700m, 23.xi.1986, M. Sharkey, sweep". Holotype and one paratype deposited in CNCI, the other paratype deposited in UB.

\section{Alloxysta nothofagi Andrews, 1976}

Diagnosis. Alloxysta nothofagi is mainly characterized having partially open radial cell, pronotal and propodeal cari- nae present, F1 subequal to pedicel in female and F1 longer than pedicel in male. It is similar to Alloxysta postica (Hartig, 1841) they could be differentiated by the coloration of the body: bicolorous in $A$. nothofagi and brown in $A$. postica; grade of pubescence at the pronotum: abundant in $A$. nothofagi and with scattered setae in A. postica; relation of length/width of the flagellomeres: bigger in A. postica than in A. nothofagi and by the host: Neuquenaphis edwardsi and Neuquenaphis schlingeri in A. nothofagi on Nothofagus antarctica and Nothofagus obliqua (Nothofagaceae) but Aphis sp. in $A$. postica on unknown host.

Short description. Head and metasoma brown, mesosoma yellowish brown; antenna yellowish brown; legs yellow and veins yellowish brown. Female antennae 13-segmented; F1F3 smooth, thinner than remaining flagellomeres, F4-F11 with rhinaria and club shaped; F1 subequal to pedicel and slightly longer than F2, F3 slightly longer than F2, F4 sightly longer than F3 (Fig. 3f). Male antennae 14-segmented; F1 smooth, thinner than remaining flagellomeres, F2-F12 with rhinaria and club shaped; F1 longer than pedicel, F1-F3 subequal in length, F3 longer than F4. Pronotum covered by abundant setae, with two thick carinae present clearly visible. Propodeum covered by setae, with two carinae forming a plate. Forewing longer than body; radial cell partially open, 2.4 times as long as wide (Fig. 5q).

Distribution. Argentina and Chile (Andrews 1976).

Type material. Deposited in MEUC (Andrews 1976: 287). Three paratypes in USNM, examined in Ferrer-Suay et al. (in press c).

\section{Alloxysta obscurata (Hartig, 1840)}

Diagnosis. Alloxysta obscurata is mainly characterized having partially open radial cell, pronotal carinae present, propodeal carinae absent, rhinaria and cub shaped begin in F3. There is no other known Alloxysta species very similar in the Neotropical region.

Short description. Head, mesosoma and metasoma dark brown; scape, pedicel, F1 and F2 dark yellow, F3-F12 yellowish brown; legs and veins yellowish brown. Female antennae 13-segmented; F1-F2 smooth, thinner than remaining flagellomeres, F3-F11 with rhinaria and club shaped; F1 longer than pedicel and F2, F2 subequal to F3, F3 shorter than F4 (Fig. 3g). Male antennae 14-segmented; F1-F3 smooth and thinner than remaining flagellomeres, F4-F12 with rhinaria and club shaped; F2 slightly curved; F1 longer than pedicel and F2, F2 longer than F3 and F3 longer than F4. Pronotum covered by setae with two long and thick carinae clearly visible. Propodeum densely covered by long setae without carinae present. Forewing longer than body; radial cell partially open, 2.7 times as long as wide (Fig. 5r).

Distribution. Holarctic region (Ferrer-Suay et al. 2012a). Colombia (Ferrer-Suay et al. 2012b).

Type material. Deposited in ZSM, examined in Ferrer-Suay et al. (in press a). 

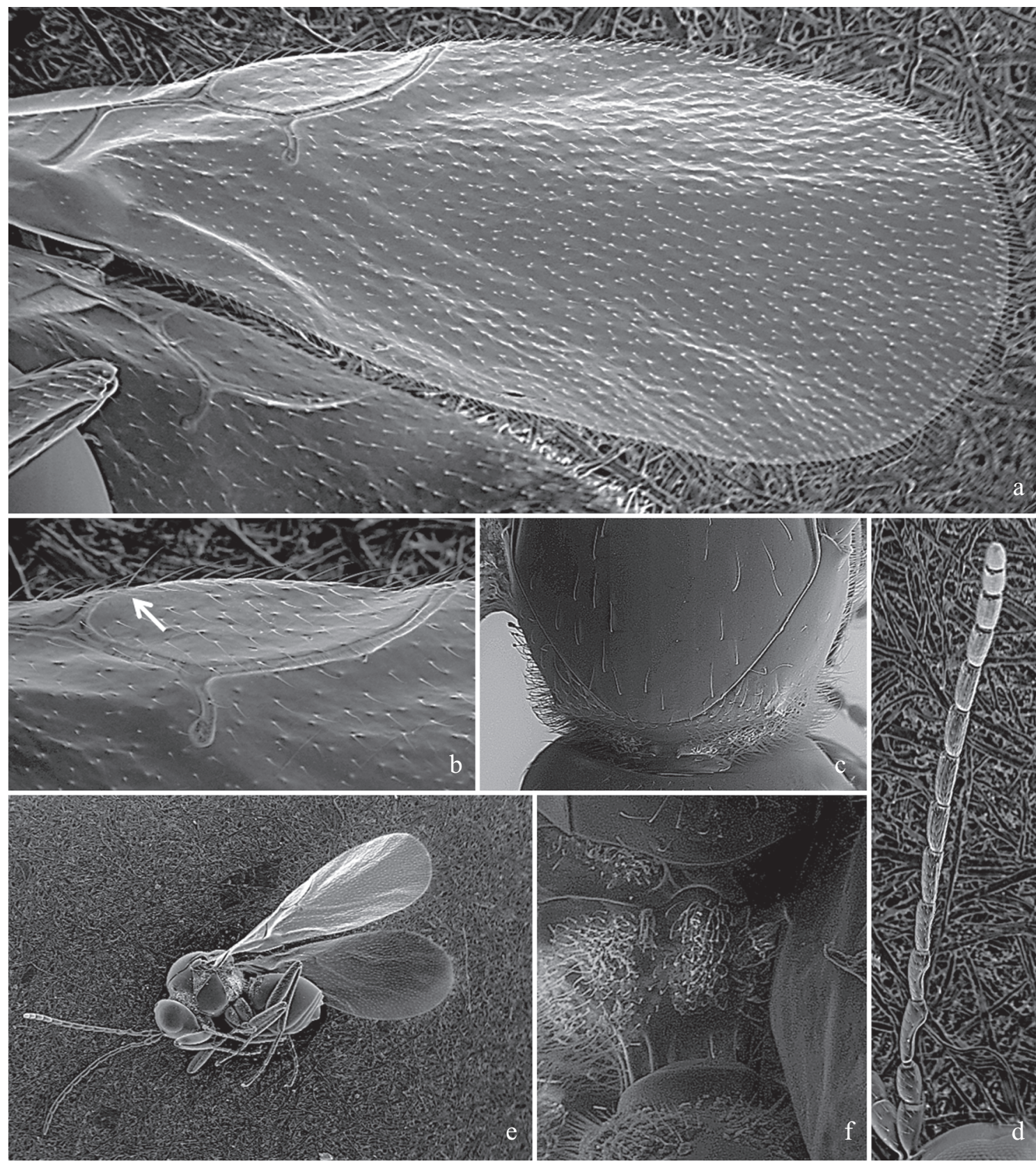

Fig. 9. Alloxysta centroamericana Ferrer-Suay \& Pujade-Villar sp. nov.: a) forewing; b) radial cell; c) pronotum; d) antenna; e) body; f) propodeum.

\section{Alloxysta piceomaculata (Cameron, 1883)}

Diagnosis. Alloxysta piceomaculata is mainly characterized having open radial cell, pronotal carinae present, propodeal carinae absent, rhinaria and club shaped begin in F4. It is similar to Alloxysta nigrita (Thomson, 1862) but they can be differentiated by the relation $\mathrm{F} 3 / \mathrm{F} 4$ : F3 subequal to $\mathrm{F} 4$ in $A$. piceomaculata (Fig. 3 h) while F3 longer than F4 in A. nigrita; and shape of radial cell: R1 and Rs not reaching the margin of the forewing in $A$. piceomaculata (Fig. $5 \mathrm{~s}$ ) but reaching in $A$. nigrita.

Short description. Head, mesosoma and metasoma yellowish brown, scape, pedicel and F1-F2 dark yellow; F3-F11 brown, legs and veins dark yellow. Female antennae 13-seg- mented; F1-F3 smooth, thinner than remaining flagellomeres, F4-F11 with rhinaria and club shaped; F1 longer than pedicel and F2, F3 slightly longer than F2, F3 subequal to F4, F4F11 subequal in length, width and shape (Fig. 3h). Pronotum covered by abundant setae, with two long and thick carinae clearly visible. Propodeum covered by abundant setae, without carinae present. Forewing longer than body; radial cell open, 2.8 times as long as wide (Fig. $5 \mathrm{~s}$ ).

Male unknown.

Distribution. Palaearctic region (Ferrer-Suay et al. 2012a). New record from the Neotropical region (Chile).

Type material. Deposited in BMNH, examined in Ferrer-Suay et al. (in press b). 
Additional examined material (2F). CNCI (1F deposited in UB): "C99Chile: $7 \mathrm{~km}$ N. Los Vilos, Choapa, $31.8508^{\circ} \mathrm{S} 70.4952^{\circ} \mathrm{W}, 215 \mathrm{~m}$, 5.xi. 1997 , M.E. Irwin, E.I. Schlinger, coastal dunes": $2 \mathrm{~F}$.

\section{Alloxysta pilipennis (Hartig, 1840)}

Diagnosis. Alloxysta pilipennis is mainly characterized having closed radial cell, pronotal and propodeal carinae present and F1 longer than pedicel. It is similar to A. pusilla but they can be differentiated by the proportion between flagellomeres in both male and female: F2 subequal to F3 in A. pilipennis female (Fig. 3i) but F2 shorter than F3 in $A$. pusilla female (Fig. 3k); F1-F3 not subequal and without any flagellomere curved in A. pilipennis male but F1-F3 subequal in lenght and slightly curved in A. pusilla male; and size of radial cell: 2.4 times in $A$. pilipennis female (Fig. 5t) but 2.7 times as long as wide in $A$. pusilla female (Fig. $5 \mathrm{v}$ ).

Short description. Head dark yellow, mesosoma yellowish brown and metasoma brown; antennae yellow darkening towards the end; legs yellow and veins yelllowish brown. Female antennae 13-segmented; F1-F2 smooth and thinner than remaining ones, F3-F11 with rhinaria and club shaped; F1 longer than pedicel and F2, F2-F4 subequal in length (Fig. 3i). Male antennae 14-segmented; as female. Pronotum entirely covered by setae with two carinae present sometimes difficult to see under the pubescence. Propodeum also covered by abundant setae, with two carinae present forming a plate with curved sides. Forewing longer than body; radial cell closed, 2.5 times as long as wide (Fig. 5t).

Distribución. Colombia (Ferrer-Suay et al. 2012b). New record from Argentina, Costa Rica, Chile, Dominican Republic, Guatemala, Panama and Venezuela.

Type material. Deposited in ZSM, examined in Ferrer-Suay et al. (in press a).

Additional examined material (9M \& 29F). CNCI (2M \& 5F deposited in UB): “C93-Chile: Chillan, 2 km W, Las Trancas, 1040m, 36 55.03'S 71'30.18'W, 5.i.2000, M. E. Irwin, E.I. Schlinger, MT near creek”: 1F; "Chile: R.V., NP La Campana, trail to Cumbre la Campana, Segundo Aquada, 32 $2^{\circ} 58.234^{\prime} S 71^{\circ} 07.528^{\prime} \mathrm{W}$ ”, “5.iii.2005, screen swep Woodland scrub, J. George CO5-044”: 1M; “C76- Colombia: 15 km, E Calarcá, Quindio, 8000', 4.iii.74, S.\&J. Peck”: 3F. USNM: “Argentina: La Rioja Prov., Santa Cruz, 31.xii.2002, P. Fidalgo, pan trap": 4F; "Colombia, Magdalena, PNN Sierra Nevada de Santa Marta, La Estación, $10^{\circ} 48^{\prime} \mathrm{N}$ $73^{\circ} 39^{\prime} \mathrm{W}, 2220 \mathrm{~m}$, Malaise, 25-30.vi.2000, J. Cantillo leg. M210": 3M \& 7F. "Colombia, Boyacá, Arcabuco SFF Iguaque, 2855m, Malaise4, Bosque Rastrojo Canon, Humarramas, 28.ii-16.iii.2000, P. Reina”: 1F. "Colombia, Boyacá, Arcabuco SFF Iguaque, 28550m, Malaise4, Bosque Rastrojo Canon Hamarramas, 28.ii-16.iii.2000, P. Reina": 1F; "C-307, Dominican Republic, Pedernales 60Km NW, Cabo Rojo, 1200m, Las Abejas, Cloud Forest, 30.XI.1991 sweeping, L. Masner \& B. Peck": 1F; "C-292, Guatemala: Zacapa, San Lorenzo, 12.VII.1986, L. La Sage sweepers, Mainty Oak": 1F; "San José, Costa Rica, 2620m, 10 mi.S. of Empalme, Cerro, Las Vueltas, 8.X.1972, J. Helava": 1F; "C105- Guatemala: Zacapa, San Lorenzo, 7-17.vii.1986, L. LeSage, PT at pine forest edge + field": 1F; "C103- Guatemala: Zacapa, below San Lorenzo, xi.1986, 750m, M. Sharkey": 1F; "C69- Guatemala: Huehuetenango, 7 km SE Todos Santos, Cuchumatan, 30.viii.1987, 2500m, M. Sharkey": 2F; "C68- Guatemala: Chimaltenango, 5 mi S. Acatenango, 2400m, 2.viii.1972, J. Helava”: 4M \& 1F; "C-142, Guatemala: Zacape Above San Lorenzo, II.1986, 8002000m, M. Sharkey": 1F; “C-269, Gatemala, Huehuetenango, 20Km NE, 2500m, 10.VIII.1987, Todos Santos Cuchumatan, Sharkey": 1F; "Panamá, Chiriqui Prov, 2Km. W. Cerro Punta, 1700m, 19.V.-8.VI.1977, Peck \& Howden": 1F; “Chile: R. ix. PN Nahuebuta, 37 49' 42"S 7300' 39”W, $1138 \mathrm{~m}$, 9-ii-2005, J. Heraty meadow \& along stream UCR ATOL C05005": 1F; "Venezuela, Tach. 55Km. N.E. Sn. Cristobal 10,000', 1718.V.1974, J. Peck": 1M.

\section{Alloxysta postica (Hartig, 1841)}

Diagnosis. Alloxysta postica is mainly characterized having partially open radial cell, pronotal carinae, propodeal carinae present, rhinaria and club shaped begin in F4. It is similar to $A$. citripes but they can be differentiated by the shape of propodeal carinae: clearly visible and forming a plate in $A$. postica while the carinae are not protruding in $A$. citripes; and size of radial cell: 2.5 times as long as wide in $A$. postica (Fig. 5u) but 2.1 times in A. citripes (Fig. 5e).

Short description. Head yellow, mesosoma and metasoma brown; scape, pedicel, F1 and F2 yellow, F4-F11 yellowish brown, legs yellow and veins yellowish. Female antennae 13segmented; F1-F3 smooth, thinner than remaining flagellomeres, F4-F11 with rhinaria and club shaped; pedicel-F4 subequal in length (Fig. 2e). Pronotum covered by setae, with two carinae clearly visible. Propodeum with many setae, with two carinae well defined and separated by setae in the first third and forming a plate with straight sides in the two last thirds. Forewing longer than body; radial cell partially open, 2.5 times as long as wide (Fig. 5e).

Male unknown.

Distribution. Central Palaearctic region (Ferrer-Suay et al. 2012a). First record from the Neotropical region (Chile).

Type material. Deposited in ZSM, examined in Ferrer-Suay et al. (in press a).

Additional examined material (8F). CNCI (4F deposited in UB): "C98Chile: Región IX, Nahuelbuta Nat. Park, 37.809' $73.016^{\circ} \mathrm{W}, 3680^{\prime}$, 912.i.2000, D.W. Webb, D.K. Yates, MT": 4F; n: 4F.

\section{Alloxysta pusilla (Kieffer, 1902)}

Diagnosis. Alloxysta pusilla is mainly characterized having closed radial cell, pronotal and propodeal carinae present and F1 longer than pedicel. It is similar to A. pilipennis but they can be differentiated by the proportion between flagellomeres in both male and female: F2 shorter than F3 in A. pusilla female (Fig. 3k) but F2 subequal to F3 in A. pilipennis female (Fig. 3i); F1-F3 subequal in lenght and slightly curved in $A$. pusilla male but F1-F3 not subequal and without any flagellomere curved in $A$. pilipennis male; and size of radial cell: 2.7 times as long as wide in A. pusilla female (Fig. 5v) but 2.4 times in A. pilipennis female (Fig. 5t).

Short description. Head, mesosoma and metasoma dark brown; scape, pedicel and F1-F3 dark yellow, F4-F12 yellowish brown; legs dark yellow and veins yellowish brown. Female antennae 13-segmented; F1-F2 smooth, thinner than remaining flagellomeres, F3-F11 with rhinaria and club shaped; F1 longer than pedicel and F2, F2 shorter than F3 and F3 shorter than F4. Male antennae 14-segmented, filiform, F1-F12 with 
rhinaria and club shaped; pedicel-F3 subequal in length, F4 longer than F3, F1-F3 slightly curved (Fig. 3k). Pronotum with few setae, two clearly visible carinae. Propodeum densely pubescent, two carinae present, separated on upper half by few setae and forming a plate on lower half, curved margins. Forewing longer than body; radial cell closed, 2.7 times as long as wide in female (Fig. 5v) and 2.4 times in male.

Distribution. Widely distributed in the Palaearctic region (Ferrer-Suay et al. 2012a). First record from the Neotropical region (Costa Rica and Guatemala).

Type material. Deposited in NHMA according to Dessart (1969: 192). It was not possible to study the type material because the collection in Amiens has not been open to consult during the last years (C. Villemant, pers. comm.).

Additional examined material (3F). CNCI ( $1 \mathrm{~F}$ deposited in $\mathrm{UB})$ : "C121, Costa Rica, 3-13.IV.1985, 3200m, H. Gowle, L. Masner”: 1F; “Guatemala: Zacapa, Dept., San Lorenzo, 12.VII.1986, sweeping L. LeSage”: 2F.

\section{Alloxysta sarae Ferrer-Suay, 2013}

Diagnosis. Alloxysta sarae is mainly characterized having a small closed radial cell, pronotal and propodeal carinae present, rhinaria and club shaped begin in F3. It is similar to $A$. arcuata but they can be differentiated by the antennae length: shorter than body length in $A$. sarae but longer in $A$. arcuata; and size of radial cell: 2.0 times as long as wide in A. sarae (Fig. 5w) while 2.3 times as long as wide in $A$. arcuata (Fig. 5b).

Short description. Head, mesosoma and metasoma dark brown; scape yellowish brown, pedicel and F1-F3 dark yellow, F4-F11 yellowish brown; legs yellow and veins yellowish brown. Female antennae 13-segmented; F1 and F2 smooth and thinner than remaining ones, F3-F11 with rhinaria and club shaped; F1 subequal to pedicel and longer than F2, F2 subequal to F3, F3 shorter than F4 (Fig. 31). Pronotum covered by sparse setae, with two thick carinae present. Propodeum covered by many setae; two propodeal carinae well defined in the first half, separated by many setae and forming a plate in the last half, with sides slightly curved. Forewing longer than body; radial cell closed, 2.0 times as long as wide (Fig. 5w).

Male unknown.

Distribution. Mexico (Ferrer-Suay et al. 2013a).

Type material. Deposited in UAEM, Morelos, examined in FerrerSuay et al. (2013a).

\section{Alloxysta torresii Ferrer-Suay \& Pujade-Villar, 2012}

Diagnosis. Alloxysta torresii is mainly characterized having closed radial cell with R1 very curved, pronotal carinae absent and propodeal carinae present. There is no other known Alloxysta species very similar present in the Neotropical region.

Short description. Head, mesosoma and metasoma dark brown; scape dark brown, pedicel and flagellomeres yellow- ish brown darkening towards the end; legs yellow and veins yellowish brown. Female antennae 13-segmented; F1 and F2 smooth and thinner than remaining ones, F3-F11 with rhinaria and club shaped; F1 longer than pedicel and F2, F2 subequal to F3, F3 shorter than F4 (Fig. 3m). Pronotum covered by setae on anterior margin and few seate on posterior margin; without carinae present. Propodeum with abundant pubescence, two propodeal carinae well defined separated and partially covered by setae on the first third and forming a plate with few carinae on the last two thirds. Forewing longer than body; radial cell closed, 1.8 times as long as wide (Fig. 5x).

Male unknown.

Distribution. Colombia (Ferrer-Suay et al. 2012b). New record from Ecuador.

Type material. Deposited in $\mathrm{IAvH}$, examined in Ferrer-Suay et al. (2012b)

Additional examined material (3F). CNCI: "Ecuador Pich. $0^{\circ} 16^{\prime}$ 'S, $78^{\circ} 36^{\prime}$ W, 3260m, 18.11.79, W.R.M. Mason": 1F. USNM: "Colombia, Boyacá, Arcabuco SFF Iguaque, 3350m, Malaise2, 28.ii-17.iii.2000, P. Reina": 1F; "Colombia, Boyacá, Arcabuco SFF Iguaque, 3450m, Malaise1, 16.iii-2.iv.2000, P. Reina”: 1F.

\section{Alloxysta victrix (Westwood, 1833)}

Diagnosis. Alloxysta victrix is mainly characterized having a big closed radial cell, pronotal carinae present, propodeal carinae absent and yellowish head. It is similar to A. fuscicornis but they can be differentiated by the color of the head: dark yellow in A. victrix but brown in A. fuscicornis; size of radial cell: 3.0 times as long as wide in $A$. victrix (Fig. 5y) while 2.7 times in A. fuscicornis (Fig. 5j); grade of pubescence on propodeum: lack of setae where the carinae are normally present in Charipinae in $A$. victrix while completely covered by setae in $A$. fuscicornis; and proportion between flagellomeres: F2-F4 subequal in A. victrix (Fig. 3n) but F2 subequal to F3, F3 shorter than F4 in A. fuscicornis (Fig. 2j).

Short description. Head dark yellow, mesosoma and metasoma dark brown; scape, pedicel, F1-F2 yellow, F3-F12 yellowish brown; legs yellow and veins brown. Female antennae 13-segmented; F1-F2 smooth, thinner than remaining flagellomeres, F3-F11 with rhinaria and club shaped; F1 longer than pedicel and F2, F2-F4 subequal (Fig. 3n). Male antennae 14-segmented, similar to female but with F1-F3 curved (F1 slightly curved while F2 and F3 clearly curved). Pronotum covered by sparse setae, two carinae clearly visible. Propodeum with abundant pubescence, no carinae present, lacking setae on longitudinal areas where carinae are present in other species. Forewing longer than body; radial cell closed, 3.0 times as long as wide (Fig. 5y).

Distribution. Cosmopolitan (Ferrer-Suay et al. 2012a). Chile (Guerra et al. 1998).

Type material. Deposited in OUMNH according to Andrews (1978: 92).

Additional examined material (1F). CNCI: "C99- Chile: 7 km N. Los Vilos, Choapa, $31.8508^{\circ} \mathrm{S} 70.4952^{\circ} \mathrm{W}, 215 \mathrm{~m}$, 5.xi.1997, M.E. Irwin, E.I. Schlinger, coastal dunes": $1 \mathrm{~F}$. 
Apocharips Fergusson, 1986 Apocharips angelicae Pujade-Villar \& Evenhuis, 2002

Diagnosis. Apocharips angelicae is easily differentiated from all other Apocharips species having many long setae under toruli.

Short description. Head, mesosoma and metasoma black; scape, pedicel, F1-F5 dark yellow, F6-F11 yellowish brown; legs and veins yellowish brown. Female antennae 13-segmented; F1-F3 smooth, thinner than remaining flagellomeres, F4-F11 with rhinaria and club shaped; F1 longer than pedicel and F2, F2 subequal to F3, F3 shorter than F4 (Fig. 4a). Pronotum with abundant setae; with two thick, curved, long carinae forming a well-defined pronotal plate. Apex of scutellum with a triangular carina $(\wedge$-shaped). Propodeum covered by abundant setae; two propodeal carinae thick, well defined, arched. Forewing longer than body; radial cell open, 2.1 times as long as wide (Fig. 6a).

Male unknown.

Distribution. Brazil (Pujade-Villar et al. 2002).

Type material. Deposited in JP-V collection (UB), examined in Pujade-Villar et al. (2002).

\section{Apocharips hansoni Menke, 1993}

Diagnosis. Apocharips hansoni is easily differentiated from all other Apocharips species having small radial carinae on face, around clypeus.

Short description. Head, mesosoma and metasoma dark brown; scape yellowish brown, pedicel and F1 dark yellow, F2-F12 yellowish brown; legs and veins yellowish brown. Female antennae 13-segmented; F1-F3 smooth, thinner than remaining flagellomeres, F4-F11 with rhinaria and club shaped; F1 longer than pedicel and F2, F2 shorter than F3, F3 shorter than F4 (Fig. 4b). Male antennae 14-segmented; F1-F3 smooth, thinner than remaining flagellomeres, F4-F12 with rhinaria and club shaped; F1 longer than pedicel and F2, F2 shorter than F3, F3 shorter than F4. Pronotum with sparse setae, less on posterodorsal margins; with two long and thick carinae. One or two carinae slightly curved at each side of apex of scutellum. Propodeum covered by abundant setae; two propodeal carinae well defined, thick, curved. Forewing longer than body; radial cell open, 2.4 times as long as wide (Fig. 6b).

Distribution. Costa Rica (Menke 1993).

Type material. Deposited in USNM \& UCR, examined in Ferrer-Suay et al. (2011).

\section{Dilyta Förster, 1869 \\ Dilyta paretasmartinezi Pujade-Villar \& Ferrer-Suay, 2012}

Diagnosis. Until now Dilyta paretasmartinezi is the only species of Dilyta present in the Neotropical region. This species is closely related to $D$. subclavata and $D$. sinica based on the presence of punctures in the distal part of metasoma, but differs from $D$. sinica in the relation pedicel/F1 (F1 longer than pedicel but not much and not arched in D. paretasmartinenzi (Fig. 4c) while in D. sinica F1 is very long and arched). Dilyta paretasmartinezi differs from D. subclavata in the beginning of rhinaria (F1 in D. paretasmartinezi (Fig. 4c) and F4 in D. subclavata).

Short description. Head, mesosoma and metasoma brown, scape yellowish brown, pedicel and F1 yellow, F2-F12 yellowish brown; legs yellow and veins yellowish brown. Male antennae 14-segmented; F1-F12 with rhinaria and club shaped. F1 slightly curved. F1-F3 subequal; F4 slightly longer than F3; F4-F12 subequal in length, width and shape. Pronotum covered with sparse setae; pronotal plate well differenciated by two lateral carinae. Mesoscutum smooth and shiny, round in dorsal view with few scattered setae. Scutellum also smooth and shiny with scatered setae present, with an $\cap$-shaped carinae on apex of scutellum. Propodeum covered with a lot of setae; with two strong broad carinae. Forewing longer than body; open radial cell, 1.8 times as long as wide (Fig. 6c). R1 short and slightly curved; Rs long and curved.

Type material. Deposited in NMW and UB, examined in Ferrer-Suay et al., 2012d.

Additional material. From Mexico (Ferrer-Suay et al. 2012d).

\section{Phaenoglyphis Förster, 1869}

\section{Phaenoglyphis americana Baker, 1896}

Diagnosis. Phaenoglyphis americana is mainly characterized having notauli, scutellum with two rounded foveae separated by a carina and open at the bottom, rhinaria and club shaped begin in different flagellomeres, rhinaria begin in F1 and club shaped begin in F2. There is no other Phaenoglyphis species closely related present in the Neotropical region.

Short description. Head, mesosoma and metasoma brown; scape, pedicel, F1-F2 yellow; F3-F12 yellowish brown; legs yellow and veins yellowish brown. Female antennae 13-segmented; F1 thinner than remaining ones, F2-F11 with club shaped, F1-F11 with rhinaria; F1 longer than pedicel, F1-F4 subequal in length, width and shape (Fig. 4d). Male antennae 14-segmented; F1 smooth and thinner than remaining flagellomeres, F2-F12 with rhinaria and club shaped; F1 curved, longer than pedicel and F2, F2 shorter than F3. Pronotum covered by sparse setae with pronotal carinae present. Mesoescutum with notauli, scutellum with two rounded foveae separated by a carina and open at the bottom. Propodeum covered by dense long setae, two carinae well defined, straight and parallel. Forewing longer than body; radial cell closed, 2.8 times as long as wide (Fig. 6d).

Distribution. Previously known from Nearctic (FerrerSuay et al. 2012a) and Neotropical regions (Mexico) (FerrerSuay et al. 2013a).

Type material. Deposited in USNM.

Additional material. From Mexico (Ferrer-Suay et al. 2013a). 


\section{Phaenoglyphis calverti Andrews, 1978}

Diagnosis. Phaenoglyphis calverti is mainly characterized not having notauli and having rounded scutellar foveae separated by a carina and open at the bottom. In the Neotropical region it is similar to $P$. falcata but they can be differentiated by the beginning of rhinaria: in F3 in P. calverti (Fig. 4e) but in F2 in P. falcata (Fig. 4f).

Short description. Head, mesosoma and metasoma dark brown; scape, pedicel and F1-F2 dark yellow, F3-F11 yellowish brown; legs and veins yellowish brown. Female antennae 13-segmented; F1-F2 smooth and thinner than remaining ones, F3-F11 with rhinaria and club shaped; F1 longer than pedicel and F2, F2 shorter than F3, F3 subequal to F4 (Fig. 4e). Male antennae 14-segmented; F1-F2 smooth and thinner than remaining flagellomeres, F3-F12 with rhinaria and club shaped; F1 curved, longer than pedicel and F2, F2 shorter than F3. Pronotum covered by many setae, distolateral corners and middle of pronotal plate almost bare, with two thick carinae clearly visible. Mesoscutum smooth and shiny, round in dorsal view with few setae. Notauli not present. Rounded scutellar foveae, separated by a carina and not delimited at the bottom. Propodeum covered by abundant pubescence; two propodeal carinae well defined on top and not defined forming a plate at the bottom, the two carinae are slightly curved. Forewing longer than body; radial cell closed, 2.7 times as long as wide.

Distribution. Previously known from Nearctic (FerrerSuay et al. 2012) and Neotropical regions (Mexico) (FerrerSuay et al. 2013a).

Type material. Deposited in USNM, examined in Ferrer-Suay et al. (in press c).

Additional material. From Mexico (Ferrer-Suay et al. 2013a)

\section{Phaenoglyphis falcata Andrews, 1978}

Diagnosis. Phaenoglyphis falcata is mainly characterized not having notauli and having rounded scutellar foveae separated by a carina and open at the bottom. In the Neotropical region it is similar to $P$. calverti but they can be differentiated by the beginning of rhinaria: in F3 in P. calverti (Fig. $4 \mathrm{e}$ ) but in F2 in P. falcata (Fig. 4f).

Short description. Head, mesosoma and metasoma dark brown; scape brown, pedicel and F1 yellow; F2-F12 yellowish brown; legs dark yellow and veins yellowish brown. Female antennae 13-segmented; F1 smooth, thinner than remaining flagellomeres, F2-F11 with rhinaria and club shaped; F1 longer than F2 and F2 subequal to F3 (Fig. 4f). Male antennae 14-segmented; F1 smooth, thinner than remaining flagellomeres, F2-F12 with rhinaria and club shaped. F1 curved. F1 longer than pedicel and F2, F2-F4 subequal in length. Pronotum covered by many setae, distolateral corners and middle of pronotal plate almost bare with two long and thick carinae clearly visible under the pubescence. Notauli not present. Rounded scutellar foveae separated by a carina and not delimited at the bottom. Propodeum covered by abundant pubescence; two propodeal carinae separated by setae only at the top and reaching the base independently. Forewing longer than body; radial cell closed, 2.9 times as long as wide.

Distribution. Previously known from Nearctic (FerrerSuay et al. 2012a) and Neotropical regions (Mexico) (FerrerSuay et al. 2013a).

Type material. Deposited in USNM, examined in Ferrer-Suay et al. (in press c).

Additional material. From Mexico (Ferrer-Suay et al. 2013a).

\section{Phaenoglyphis stenos Andrews, 1978}

Diagnosis. Phaenoglyhis stenos is mainly characterized having notauli, rhinaria and club shaped begin in F2 and scutellar foveae slightly fused. In the Neotropical region it is similar to $P$. stricta but they can be differentiated by the beginning of rhinaria and club shaped: in F2 in P. stenos (Fig. $4 \mathrm{~g}$ ) but F1 in P. stricta (Fig. 4h); proportion between flagellomeres: F2-F3 not subequal in length in P. stenos (Fig. $4 \mathrm{~g}$ ) but subequal in P. stricta (Fig. 4h); shape of scutellar foveae: slightly fused in $P$. stenos while well separated by a carinae in P. stricta; size of radial cell: 2.9 times as long as wide in P. stenos but 2.4 times in P. stricta.

Short description. Head, mesosoma and metasoma dark brown; scape brown, pedicel and F1-F11 yellow; legs and veins yellow. Female antennae 13-segmented; F1 smooth and thinner than remaining ones, F2-F11 with rhinaria and club shaped; F1 longer than pedicel and F2, F2 subequal to F3, F3 shorter than F4 (Fig. 4g). Pronotum covered by sparse setae with pronotal carinae present. Mesoescutum with notauli, scutellum with two rounded foveae slightly fused and open at the bottom. Propodeum covered by dense long setae, two carinae well defined, slightly curved. Forewing longer than body; radial cell closed, 2.9 times as long as wide.

Male unknown.

Distribution. Previously known from Nearctic (FerrerSuay et al. 2012a) and Neotropical regions (Mexico) (FerrerSuay et al. 2013a).

Type material. Deposited in USNM, examined in Ferrer-Suay et al. (in press c).

Additional material. From Mexico (Ferrer-Suay et al. 2013a).

Additional examined material: (1F) CNCI: "C106- Guatemala: Sacatepequez, above Antigua Guatemala, Volcán Agua, 1700m, 23.xi.1986, M. Sharkey, sweep": 1F.

\section{Phaenoglyphis stricta (Thomson, 1877)}

Diagnosis. Phaenoglyphis stricta is mainly characterized having notauli present; rhinaria and club shaped begin in F1, scutellar foveae separated by a carina not delimited on both the top and the bottom. In the Neotropical region it is similar to $P$. stenos but they can be differentiated by the beginning of rhinaria and club shaped: in F1 in P. stricta (Fig. 4h) but in 
F2 in P. stenos (Fig. 4g); proportion between flagellomeres: F2-F3 subequal in length in P. stricta (Fig. 4h) but not subequal in P. stenos (Fig. 4g); shape of scutellar foveae: well separated by a carinae in $P$. stricta while slightly fused in P. stenos; size of radial cell: 2.4 times as long as wide in $P$. stricta but 2.9 times in $P$. stenos.

Short description. Head, mesosoma and metasoma dark brown; scape yellowish brown, pedicel, F1 and F2 dark yellow, F3-F11 yellowish brown; legs and veins dark yellow. Female antennae 13-segmented; rhinaria and club shape begin on the last two thirds of F1; F1 longer than pedicel and F2, F2-F4 subequal in length (Fig. 4h). Pronotum entirely covered by many setae; with two thick carinae clearly visible under the pubescence. Notauli present. Oval scutellar foveae present, separated by a carina and not delimited both at the top and at the bottom. Propodeum covered by many setae with two carinae straight and parallel, reaching the base independently. Forewing longer than body; radial cell closed, 2.4 times as long as wide.

Male unknown.

Distribution. Previously known from Palearctic (FerrerSuay et al. 2012a) and Neotropical regions (Mexico) (FerrerSuay et al. 2013a).

Type material. Deposited in USNM, examined in Ferrer-Suay et al. (in press c).

Additional material. From Mexico (Ferrer-Suay et al. 2013a)

\section{Phaenoglyphis villosa (Hartig, 1841)}

Diagnosis. Phaenoglyphis villosa is easily differentiated from the other Phaenoglyphis species by having the radial cell partially open (Fig. 6e), the rest of Phaenoglyphis species have the radial cell closed.

Short description. Head, mesosoma and metasoma dark brown to blackish-brown; scape, pedicel, F1-F2 and sometimes F3 yellow to light brown, subsequent flagellomeres dark, reddish-brown; legs yellow and veins yellowish to brownish. Female antennae 13-segmented; F1 and F2 smooth and thinner than remaining ones, F3-F11 with rhinaria and club shaped; F1 as long as pedicel or slightly longer, F1 subequal to F2, F2 shorter than F3, F3 shorter than F4 (Fig. 4i). Male antennae 14-segmented; F1 and F2 smooth and thinner than remaining flagellomeres, F3-F12 with rhinaria and club shaped; F1 slightly bowed and longer than pedicel, F1 subequal to F2, F2 shorter than F3. Pronotum covered by sparse setae with pronotal carinae present. Mesoescutum without notauli, scutellum with two deep oval foveae more or less separated by a carina or completely fused. Propodeum covered by dense long setae, two carinae well defined, straight and parallel. Forewing longer than body; radial cell partially open, 2.1-2.7 times as long as wide (Fig. 6e).

Distribution. Cosmopolitan (Ferrer-Suay et al. 2012a). Argentina and Chile (Pujade-Villar et al. 2002), Mexico (Ferrer-Suay et al. 2013a) and Colombia (Ferrer-Suay et al. 2012b). New record from Uruguay.
Type material. Deposited in ZSM, examined in Ferrer-Suay et al. (in press a).

Additional examined material (72F) BMNH: "Ex. Aphidius ervi", "Dr. F. Zunigo La Cruz, Chile, Rec. 10.v.77": 1F; "Colombia, Puente Predia, Bogotá, 20.xii.82", "ex. Myzus persicae on Chrysanthemum BJ 009, C.I.E.A 14984”, "Phaenoglyphis ambrosiae (Ashmead) det. J. Quinlan, 1983": 1F; "Yellow pan trap", "ARG: Santa Cruz, Punta Loyola 37K, e Rio Gallegos,18.i.1998, C. \& M. Vardy", "C.R. Vardy Coll. BMNH (E) 2008-81": 1F; "Uruguay: Colonia del Sacramento, 14.vi.1992: H.S.R. Cobette", "K-J. Hedqvist coll. BMNH-ENT-2001-27": 2F. CNCI_(10F deposited in UB): "C94- Chile: S. Colina-Santiago, El Partezuelo, xi.1978": 23F; "C97- Chile, Curicó, 15 km E, Curicó, Loma, HuecaHuecan, $35.0665^{\circ} \mathrm{S} 71.1226^{\circ} \mathrm{W}, 400 \mathrm{~m}, 29 . \mathrm{x}-8 . x i .1997$, J.E. Baniga, M.E. Irwin, MT on dry hillside,": 1F; “C91- Chile: Curicó, 15 km, E. Curicó, Loura Hueca-Huecan, $35.0665^{\circ} \mathrm{S} 71.1226^{\circ} \mathrm{W}, 400 \mathrm{~m}$, 9-xii-1997, D.W. Webb, MT on dry hillside": 1F; "C90- Chile: Quillota, Campanas Nat. Park, $32.932^{\circ} \mathrm{S} 71.078^{\circ} \mathrm{W}, 29 . x i .1999-13 . i .2000$, M. Irwin, 250m, MT”: 2F; "C100- Chile: Valparaiso, Fundo Sta. Rita, 6-20.xi.1997, M.E. Irwin, E.I. Schlinger, MT in sandy depression": 5F; "C88- Chile: Elqui, $24 \mathrm{~km}$ S. Vienna, 1.xi.1992, Rozen, Sharkov \& Snyder": 1F; “C99- Chile: 7 km N. Los Vilos, Choapa, $31.8508^{\circ} \mathrm{S} 70.4952^{\circ} \mathrm{W}, 215 \mathrm{~m}, 5 . x i .1997$, M.E. Irwin, E.I. Schlinger, coastal dunes": 10F; "C93- Chile: Chillan, $2 \mathrm{~km} \mathrm{W,} \mathrm{Las}$ Trancas, $1040 \mathrm{~m}, 36^{\circ} 55.03^{\prime} \mathrm{S}$ 7130.18'W, 5.i.2000, M. E. Irwin, E.I. Schlinger, MT near creek": 1F; "C95- Chile: Santiago, Quebrada la Plata, $5 \mathrm{~km}$ W La Rinconada de Maipú, $33.4984^{\circ} \mathrm{S} 70.9042^{\circ} \mathrm{W}, 400 \mathrm{~m}, 31 . \mathrm{x}-$ 10.xi.1997, G. Burnis, M.E. Irwin, MT”: 6F; “C96- Chile: Quillota, Palma de Ocoa, Campanas Nat. Park, 32.9324으 $71.0781^{\circ} \mathrm{W}, 13-20 . x i .1997$, M.E. Irwin E.I. Schlinger, $215 \mathrm{~m}$, MT in hillside draw": 17F.

\section{DISCUSSION}

Charipinae species present in the Neotropical region have been revised in this study. Andrews (1976) was the first author who described a species from this biogeographical region: Alloxysta nothofagi from Argentina and Chile. Later, Menke (1993) described Apocharips hansoni from Costa Rica; mainly characterized being the only species in the genus Apocharips with small radial carinae around clypeus.

Pujade-Villar et al. (2002) established that five Charipinae species were present in South America: Alloxysta desantisi, Alloxysta fuscicornis, Phaenoglyphis villosa, Apocharips angelicae and Apocharips hansoni. In this paper two new species were recorded: Alloxysta desantisi from Argentina, Brazil and Chile and Apocharips angelicae from Brazil. More recently, Paretas-Martínez \& Pujade-Villar (2007) also revised the Charipinae present in the Neotropical region and proposed the existence of nine new morphotypes that possibly are new species.

The authors of this work have already revised Charipinae material from different countries belonging to the Neotropical region. Ferrer-Suay et al. (2011) studied the Charipinae from Costa Rica, describing four new species: Alloxysta andrewsi; Alloxysta costaricensis; Alloxysta hansoni and Alloxysta luismii. Moreover, in this study the description of Apocharips hansoni is improved by discussion of the radial cell and Alloxysta halli is cited for the first time from Costa Rica. Charipinae from Colombia have also been studied (Ferrer-Suay et al. 2012b) resulting in six new records from this region and two new species: Alloxysta medinae and Alloxysta torresii. Charipinae material from México has been 
also revised (Ferrer-Suay et al. 2013a). In this study 12 Charipinae species are cited for the first time and three new species are described: Alloxysta evenhuisi, Alloxysta mexicana and Alloxysta sarae. Additionaly, in Ferrer-Suay et al. (2012d) the first record of Dilyta from the Neotropical region was established, Dilyta paretasmartinezi Pujade-Villar \& FerrerSuay, 2012.

A key to identify all the Charipinae species present in the Neotropical region is presented below.

1. Metasoma with a single tergal plate, or if two, then basal tergite much shorter than second along middorsal line (Fig. 1d) . (Apocharips or Dilyta)

1 '. Metasoma with two large visible terga, subequal in length along middorsal line, but basal tergite 1/4-1/3 smaller than second in lateral view (Fig. 1c) .............. (Alloxysta or Phaaenoglyphis)

2. Metasoma with a single tergal plate .... Dilyta Förster, 1869

... Dilyta paretasmartinezi Pujade-Villar \& Ferrer-Suay, 2012

2'. Metasoma with two tergal plates, basal tergite much shorter than second along middorsal line (Fig. 1d) ...... Apocharips Fergusson, 1986

3

3. Lower face with small radial carinae around clypeus. Two last flagellomeres broadly joined. Toruli with few short setae ventrally ............Apocharips hansoni Menke, 1993

3'. Face smooth, without carinae. Two last flagellomeres well differentiated, not broadly joined. Toruli with many short setae ventrally

.. Apocharips angelicae Pujade-Villar \& Evenhuis, 2002

4. Lower part of mesopleuron with horizontal sulcus (Fig. 1a) Phaenoglyphis Förster, 1869

4'. Mesopleuron lacking horizontal sulcus (Fig. 1b) Alloxysta Förster, 1869

5. Notaulices present, at least in the posterior half of mesoscutum and/or scutum sculptured

6

5 '. Notaulices completely absent and scutum smooth and shining.....

6. Female antennae: rhinaria begin on F1 and club shape begin on F2 (Fig. 4d). Male antennae: rhinaria and club shape begin on F2, F1 very curved and longer than pedicel and F2, F2 shorter than F3, F3 subequal to F4

Phaenoglyphis americana Baker, 1896

6'. Female antennae: rhinaria and club shape begin on the same flagellomere. Male antennae: rhinaria and club shape begin in different flagellomeres, different proportion between flagellomeres

7. Rhinaria and club shape begin on F2, F2-F3 not subequal in length (Fig. 4g). Scutellar foveae slightly fused. Radial cell 2.9 times as long as wide. Male unknown.....

Phaenoglyphis stenos Andrews, 1978

7'. Rhinaria and club shape begin on the last two thirds of F1, F2-F3 subequal in length (Fig. 4h). Oval scutellar foveae present, separated by a carina and not delimited both at the top and at the bottom. Radial cell 2.4 times as long as wide. Male unknown ....

. Phaenoglyphis stricta (Thomson, 1877)

8. Radial cell partially open along anterior margin (Fig. 6e). Rounded scutellar foveae, sometimes slightly fused ......

Phaenoglyphis villosa (Hartig, 1841)

8'. Radial cell closed (like Fig. 6d). Rounded scutellar foveae separated by a carina 9

9. Rhinaria and club shape begin on F2 (Fig. 4f) Phaenoglyphis falcata Andrews, 1978

9'. Rhinaria and club shape begin on F3 (Fig. 4e)

Phaenoglyphis calverti Andrews, 1978

10. Radial cell open or partially open ............................. 11

10'. Radial cell closed .................................................... 22

11. Radial cell completely open ..................................... 12

11'. Radial cell partially open ........................................ 15

12. Propodeal carinae absent .......................................... 13

12'. Propodeal carinae present ....................................... 14

13. Female: rhinaria and club shape begin in F4 (Fig. 3h). Radial cell 2.8 times as long as wide (Fig. $5 \mathrm{~s}$ ). Male unknown ........... Alloxysta piceomaculata (Cameron, 1883)

13'. Female unknown. Male: rhinaria and club shape begin in F1 (Fig. 9d). Radial cell 4.1 times as long as wide (Fig. 9b). Alloxysta centroamericana Ferrer-Suay \& PujadeVillar sp. nov.

14. Female and male: rhinaria and club shape begin in F3; F2 subequal to F3, F3 shorter than F4 (Fig. 3b). Radial cell 2.5 times as long as wide (Fig. $5 \mathrm{~m}$ )...

... Alloxysta medinae Ferrer-Suay \& Pujade-Villar, 2012

14'. Female and male: rhinaria and club shape begin in F4; F1-F4 subequal in length (Fig. 2f). Radial cell 3.2 times as long as wide (Fig. 5f) Alloxysta costaricensis Ferrer-Suay \& Pujade-Villar, 2011

15. Propodeal carinae absent Alloxysta obscurata (Hartig, 1840)

15'. Propodeal carinae present, forming a plate 16

16. Rhinaria and club shape begin in different flagellomeres (Fig. 3a) Alloxysta luismii Ferrer-Suay, 2011

16 '. Rhinaria and club shape begin in the same flagellomeres

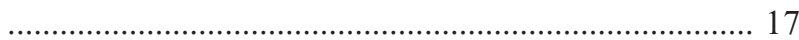

17. F1 subequal to pedicel in both male and female ....... 18 17'. F1 longer than pedicel in both male and female ...... 20

18. Propodeal carinae not protruding. Radial cell 2.1 times as long as wide (Fig. 5e)

Alloxysta citripes (Thomson, 1862)

18 '. Propodeal carinae well defined and protruding. Radial cell longer than 2.1 times as long as wide. 19

19. Body brown. Scattered setae in the pronotum. Known in Aphis spp. Alloxysta postica (Hartig, 1841) 
19'. Body bicolorous (yellow and brown). Abundant pubescence in the pronotum. Known in Neuquenaphis spp. ...

Alloxysta nothofagi Andrews, 1976

20. F2 subequal to F3, F3 shorter than F4 (Fig. 2a) ... Alloxysta andrewsi Ferrer-Suay \& Pujade-Villar, 2011

20'. F2-F4 subequal in length 21

21. Female and male: F1 longer than F2, F2 subequal to F3 (Fig. 2d). Radial cell 2.3 times as long as wide (Fig. 5d) Alloxysta castanea (Hartig, 1841)

21'. Female: pedicel-F3 subequal in length (Fig. 3c). Male: F1 longer than pedicel and F2, F2 subequal to F3. Radial cell 2.0 times as long as wide (Fig. 5n).... Alloxysta melanogaster (Hartig, 1840)

22. Propodeal carinae present 23

22'. Propodeal carinae absent 34

23. Pronotal carinae absent 24

23'. Pronotal carinae present 28

24. Female unknown. Rhinaria and club shape begin on first third of F1 (Fig. 3d) .

.. Alloxysta mexicana Ferrer-Suay \& Pujade-Villar, 2013

24'. Rhinaria and club shape begin on different flagellomeres 25

25. Rhinaria and club shape begin in F3 (Fig. 3m). Radial cell 1.8 times as long as wide, Rs very curved (Fig. 5x) ...... Alloxysta torresii Ferrer-Suay \& Pujade-Villar, 2012

25'. Rhinaria and club shape begin in F4. Radial cell longer than 1.8 times as long as wide, Rs slightly curved ..... 26

26. Antennae shorter than body length. F1 shorter than pedicel, F1-F3 subequal in length (Fig. 2c). Radial cell 2.1 times as long as wide (Fig. 5c) .....

Alloxysta brevis (Thomson, 1862)

26 '. Antennae longer than body length. F1 subequal or longer than pedicel, F1-F3 not subequal in length. Radial cell longer than 2.1 times as long as wide 27

27. F1 longer than pedicel, F1-F3 subequal in length (Fig. 2i). Male: F3 curved

Alloxysta fracticornis (Thomson, 1862)

27'. F1 subequal to pedicel, F1 longer than F2, F2 subequal to F3 (Fig. 3e). Male: without any flagellomere curved . Alloxysta mullensis (Cameron, 1883)

28. F1 subequal to pedicel

28'. F1 longer than pedicel 30

29. Antennae longer than body length. Male: F2 slightly curved; radial cell 2.3 times as long as wide (Fig. 5b) ...

Alloxysta arcuata (Kieffer, 1902)

29'. Antennae shorter than body length; radial cell 2.0 times as long as wide (Fig. 5w). Male unknown

Alloxysta sarae Ferrer-Suay, 2013

30. Rhinaria and club shape begin in F2 (Fig. 2h) ..... .. Alloxysta evenhuisi Ferrer-Suay \& Pujade-Villar, 2013

30'. Rhinaria and club shape begin in different flagellomeres
31. Rhinaria and club shape begin in F3 32

31 '. Rhinaria and club shape begin in F4 33

32. Female: F1-F3 subequal in length (Fig. 2g). Male: without any flagellomere curved

Alloxysta desantisi Pujade-Villar \& Díaz, 2002

32'. Female: F2 shorter than F3, F3 shorter than F4 (Fig. 2k). Male: F1 slightly curved ....

Alloxysta hansoni Pujade-Villar, 2011

33. Female: F2 shorter than F3 (Fig. 3k). Male: rhinaria begin in F1, pedicel-F3 subequal and slightly curved. Propodeal plate with slightly curved sides. Radial cell 2.7 times as long as wide in female (Fig. 5v) and 2.4 times as long as wide in male .... Alloxysta pusilla (Kieffer, 1902) 33'. Female: F2 subequal to F3 (Fig 3i). Male: rhinaria begin in F2, pedicel-F3 not subequal, without any flagellomere curved. Propodeal plate with strongly curved sides. Radial cell 2.4 times as long as wide in both male and female (Fig. 5t) Alloxysta pilipennis (Hartig, 1840)

34. Head yellowish. F2-F4 subequal in length (Fig. 3n). Radial cell 3.0 times as long as wide (Fig. 5y). Propodeum without setae in the longitudinal area where the carinae are present in other Charipinae (Fig. 7b)

Alloxysta victrix (Westwood, 1833)

34'. Head brown. F2-F4 not subequal (Fig. 2j). Radial cell 2.7 times as long as wide (Fig. 5j). Propodeum entirely covered by setae ..... Alloxysta fuscicornis (Hartig, 1841)

\section{ACKNOWLEDGEMENTS}

We are very grateful to John Huber for allowing us to study all the malaise trap material in alcohol deposited at the Canadian National Collection of Insects, where we found the specimens used for this study. We also want to thank to David Notton and Matthew Buffington for their hospitality during our stay at the Natural History Museum (London, United Kingdom) and the United States National Museum of Natural History (Smithsonian Institution) (Washington, United States), respectively. We are also very grateful to Claire Villemant (Muséum National d'Histoire Naturelle, Paris, France) for the information about the Amiens Museum. This research was supported by the projects CGL2008-00180 and CGL2011-22889 of the Ministerio de Ciencia e Innovación (Spain) and the grant AP2009-4833 of the Ministerio de Educación (Spain).

\section{REFERENCES}

Andrews, F.G. 1976. A new species of Alloxysta hyperparasitic on aphids associated with South American Nothofagus forest. Pan-Pacific Entomologist 52: 256-257.

Andrews, F.G. 1978. Taxonomy and host specificity of Nearctic Alloxystinae with a catalogue of the world species (Hymenoptera: Cynipidae). Occasional Papers in Entomology 25: 1-128.

Berta, D.C., Colomo, M.V. \& Ovruski, N.E. 2002. Interrelaciones entre los áfidos colonizadores del tomate y sus himenópteros parasitoides en Tucamán (Argentina). Boletín de Sanidad Vegetal Plagas 28: 6777. 
Betini, A. 1975. Afideos da macieira (Pyrus malus L.), seus predadores e parasitas. Acta Biologica Paranaense 4: 33-74.

Betini, A. 1976. Afideos da ameixeira (Prunus domestica L.) e pessegueiro (Prunus persica sto.), seus predadores e parasitas. Acta Biologica Paranaense 5: 69-90.

Cividanes, F.J. 2002. Impacto de inimigos naturais e de fatores meteorológicos sobre uma população de Brevicoryne brassicae (L.) (Hemiptera: Aphididae) em couve. Neotropical Entomology 31: 249-255.

De Santis, L. 1937. El hiperparasito del pulgón verde de los cereales. Boletin del Laboratorio de Zoologia Agricola, Facultad de Agronomia, Universidad de La Plata 3: 14-16.

Dessart, P. 1969. Les types de Cynipidae décrits par l'abbé Jean-Jaques Kieffer, conservés dans la collection Léon Carpentier au Musée d'Histoire naturelle d'Amiens (France). Bulletin et Annales de la Société Royale Entomologique de Belgique 105: 180-201.

Ferrer-Suay, M., Selfa, J. \& Pujade-Villar, J. 2011. First record of Alloxysta Förster (Hymenoptera: Figitidae) from Costa Rica, with description of four new species. Neotropical Entomology 40: 689-697.

Ferrer-Suay, M., Paretas-Martínez, J., Selfa, J. \& Pujade-Villar, J. 2012a. Taxonomic and synonymic world catalogue of the Charipinae and notes about this subfamily (Hymenoptera: Cynipoidea: Figitidae). Zootaxa 3376: 1-92.

Ferrer-Suay, M., Selfa, J. \& Pujade-Villar, J. 2012b. Revisión de la fauna de charipinos (Hymenoptera: Figitidae: Charipinae) de Colombia, con la descripción de dos nuevas especies y claves para su identificación. Revista Colombiana de Entomología 38: 320-328.

Ferrer-Suay, M., Selfa, J. \& Pujade-Villar, J. 2012c. Taxonomic revision of Alloxysta brevis complex (Cynipoidea: Figitidae: Charipinae). Boletín de la Sociedad Aragonesa de Entomología 51: 237-259.

Ferrer-Suay, M., Selfa, J. \& Pujade-Villar, J. 2012d. Estado actual del conocimiento de los charipinos (Hymenoptera: Figitidae) en México y primera cita del género Dilyta para el neotropico. Entomología Mexicana 11: 1051-1056.

Ferrer-Suay, M., Selfa, J., Equihua-Martínez, A., Estrada-Venegas, E., Lomeli-Flores, R., Peña Martínez, R. \& Pujade-Villar, J. 2013a. Charipinae from Mexico with description of three new species and including key (Hymenoptera: Cynipoidea: Figitidae). Annals of the Entomological Society of America 106: 26-41.

Ferrer-Suay, M., Selfa, J. \& Pujade-Villar, J. 2013b. Revision of Thomson and Zetterstedt collections of Alloxysta genus deposited in Lund Museum of Zoology (Sweden). Entomologisk Tidskrift 134: 77-102.

Ferrer-Suay, M., Selfa, J., \& Pujade-Villar, J. Revision of Hartig collection of Alloxysta genus deposited in Zoologische Staatssammlung Museum (Munich). Mitteilungen der Münchner Entomologischen Gesellschaft, in press a.

Ferrer-Suay, M., Selfa, J., Notton, D. \& Pujade-Villar, J. Revision of
Cameron and Fergusson collections related with Alloxysta genus (Hym., Figitidae: Charipinae) deposited in Natural History Museum (London). European Journal of Taxonomy, in press b.

Ferrer-Suay, M., Selfa, J. \& Pujade-Villar, J. The Alloxysta type material (Hym., Figitidae: Charipinae) in the National Museum of Natural History, Washington, DC and the Canadian National Collection of Insects, Ottawa. Canadian Entomologist, in press c.

Guerra, M., Fuentes-Contreras, E. \& Niemeyer, H.M. 1998. Differences in behavioral responses of Sitobionn avenae (Hemiptera: Aphididae) to volatile compounds, following parasitism by Aphidius ervi (Hymenopteta: Braconidae). Écoscience 5: 334-337.

Lazzari, S.N. 1985. Inimigos naturais dos afideos (Homoptera, Aphididae) da cevada (Hordeum sp.) no Paraná. Anais da Sociedade Entomológica do Brasil 14: 5-15.

Menke, A.S. \& Evenhuis, H.H. 1991. North American Charipidae: key to genera, nomenclature, species checklists, and a new species of Dilyta Förster (Hymenoptera: Cynipoidea). Proceedings of the Entomological Society of Washington 93: 136-158.

Menke, A.S. 1993. A new species of Apocharips from Costa Rica (Hymenoptera: Cynipoidea, Charipidae). Journal of Hymenoptera Research 2: 97-100.

Paretas-Martínez, J. \& Pujade-Villar, J. 2007. Revisión de los Charipinae de la región Neotropical (Hymenoptera: Figitidae). Entomología Mexicana 6: $1344-1348$.

Paretas-Martínez, J., Arnedo, M.A., Melika, G., Selfa, J., Seco-Fernández, M.V., Fülop, D. \& Pujade-Villar, J. 2007. Phylogeny of the parasitic wasp subfamily Charipinae (Hymenoptera, Cynipoidea, Figitidae). Zoologica Scripta 36: 153-172.

Pujade-Villar, J., Díaz, N., Evenhuis, H.H. \& Ros-Farré, P. 2002. South American Charipinae: Review and description of two new species (Hymenoptera: Cynipoidea: Figitidae). Annals of the Entomological Society of America 95: 541-546.

Pujade-Villar, J., Ferrer-Suay, M.M., Selfa, J., \& Caicedo-Ramírez, G. 2010b. Primera cita de Charipinae (Hym., Figitidae) para Colombia. Boletín del Museo de Entomología de la Universidad del Valle 11: 28-32.

Tavares, M.T. 1991. Interação Planta/Afídeo/Parasitóides e Hiperparasitóides em Ambientes Naturais e Antrópicos. M. Sc. Thesis. Universidade Federal de São Carlos, São Carlos, Brazil.

Vaz, L.A.L., Tavares, M.T. \& Lomônaco, C. 2004. Diversidade e tamanho de himenópteros parasitóides de Brevicoryne brassicae L. e Aphis nerii Boyer de Fonscolombe (Hemiptera: Aphididae). Neotropical Entomology 30: 225-230.

Westwood, J.O. 1833. Notice of the habits of a cynipideous insect, parasitic upon the rose louse (Aphis rosae); with descriptions of several other parasitic Hymenoptera. Magazine of Natural History 6: 491-497.

Received 14 March 2013; accepted 14 May 2013

Associate Editor: Kevin A. Williams 